\title{
El estilo Ychsma: características generales, secuencia y distribución geográfica
}

Le style Ychsma: Caractéristiques générales, séquence et distribution géographique

Ychsma Style: General Characteristics, Sequence and Geographical Distribution

\section{Francisco Vallejo Berríos}

\section{(2) OpenEdition}

Journals

Edición electrónica

URL: https://journals.openedition.org/bifea/5165

DOI: $10.4000 /$ bifea.5165

ISSN: 2076-5827

Editor

Institut Français d'Études Andines

Edición impresa

Fecha de publicación: 1 diciembre 2004

Paginación: 595-642

ISSN: 0303-7495

Referencia electrónica

Francisco Vallejo Berríos, «El estilo Ychsma: características generales, secuencia y distribución geográfica», Bulletin de l'Institut français d'études andines [En línea], 33 (3) | 2004, Publicado el 08 diciembre 2004, consultado el 21 septiembre 2021. URL: http://journals.openedition.org/bifea/5165; DOI: https://doi.org/10.4000/bifea.5165

\section{(c) () 8 ()}

Les contenus du Bulletin de l'Institut français d'études andines sont mis à disposition selon les termes de la licence Creative Commons Attribution - Pas d'Utilisation Commerciale - Pas de Modification 4.0 International. 
Bull. Inst. fr. études andines

2004, 33 (3): 595-642

\section{EL ESTILO YCHSMA: CARACTERÍSTICAS GENERALES, SECUENCIA Y DISTRIBUCIÓN GEOGRÁFICA}

Francisco VALLEJO BERRÍOS *

\section{Resumen}

Las recientes investigaciones arqueológicas que hemos venido realizando en los sitios de La Rinconada y Armatambo, así como la revisión de material cerámico proveniente de diversos sitios como Macattampu, Pachacamac, entre otros, han permitido elaborar un cuadro básico de la secuencia cerámica Ychsma; definir sus características generales en cada una de sus fases comprendidas y esbozar un espacio de distribución geográfica a partir de material comparativo de los valles del Rímac, Lurín, Chilca y Mala, sumándose también material proveniente de valles vecinos.

La necesidad de establecer los parámetros básicos del corpus cerámico Ychsma, como también encontrar su relación secuencial a partir del marco creado por los dos grandes horizontes temporales, el que le antecede y el que le sucede respectivamente, se ha convertido en una de las premisas fundamentales en la mayoría de investigaciones arqueológicas desarrolladas en cada uno de los valles mencionados.

Por ello, este trabajo apunta principalmente al estudio de la cerámica como importante marcador temporal a partir de su desarrollo estilístico y a los contextos arqueológicos asociados con ella, de acuerdo con la relación estratigráfica presente.

Palabras claves: Estilo Ychsma, Pachacamac, Armatambo, periodo Intermedio Tardío, periodo Inca, cerámica Ychsma.

\section{LE STYLE YCHSMA : CARACTÉRISTIQUES GÉNÉRALES, SÉQUENCE ET DISTRIBUTION GÉOGRAPHIQUE}

\section{Résumé}

Des recherches archéologiques récentes menées sur les sites de La Rinconada et Armatambo, ainsi qu'une révision du matériel céramique de plusieurs sites tels que Macattampu et Pachacamac, entre autres, nous ont permis de tracer une première ébauche de la séquence

\footnotetext{
*Co-director del Proyecto Arqueológico Armatambo. Correo: f_vallejob@yahoo.com
} 
céramique Ychsma, de définir les caractéristiques générales de chacune de ses phases et d'esquisser sa distribution géographique, tout cela en ayant recours à du matériel de comparaison issu des vallées du Rímac, du Lurín, du Chilca et du Mala, ainsi qu'à du matériel supplémentaire provenant des vallées voisines. L'un des principaux buts de la majorité des recherches menées dans ces vallées a été d'établir les paramètres essentiels du corpus de la céramique Ychsma et de définir comment celle-ci s'intègre au cadre fixé par les deux grands horizons qui la précèdent et la suivent. Le présent travail s'attache donc essentiellement à l'analyse de la céramique en tant que marqueur temporel via son développement stylistique et les contextes archéologiques qui lui sont associés, conformément aux informations fournies par la stratigraphie.

Mots clés : Style Ychsma, Pachacamac, Armatambo, Période Intermédiaire récent, Période Inca, céramique Ychsma.

\title{
YCHSMA STYLE: GENERAL CHARACTERISTICS, SEQUENCE AND GEOGRAPHICAL DISTRIBUTION
}

\begin{abstract}
Recent archaeological research at the sites of La Rinconada and Armatambo and a revision of ceramic material from several sites such as Macattampu and Pachacamac, among others, have enabled us to form a basic picture of the Ychsma ceramic sequence ; to define its general features for each of its phases and to outline its geographical distribution, using comparative material from the Rimac, Lurin, Chilca and Mala valleys as well as additional material from other neighbouring valleys.

One of the principal goals driving much of the archaeological research carried out in the above-mentioned valleys has been to establish the basic parameters of the Ychsma ceramic corpus, as well as to define how it fits into the framework established by the two great horizons that precede and succeed it. Hence the present work is mainly concerned with the analysis of ceramic data as an important temporal marker via its stylistic development and the archaeological contexts associated with it in accordance with the information provided by current stratigraphy.

Key words: The Ychsma style, Pachacamac, Armatambo, the Late Intermediate Period, the Inca Period, Ychsma ceramics.
\end{abstract}

\section{LA CERÁMICA YCHSMA}

Si bien Pachacamac y, recientemente, varios de los sitios arqueológicos pertenecientes a la sociedad Ychsma han sido sujeto de muchas investigaciones, es contradictorio que su cerámica haya sido apenas descrita, faltando, por supuesto, realizar una seriación completa de la misma. De hecho, el problema de definición de la cerámica Ychsma es uno de los más importantes, si se quiere conocer las principales características arqueológicas y cronológicas de esta sociedad.

Varios investigadores ya han efectuado algunos análisis iniciales y esbozado modelos de clasificación de la cerámica Ychsma, incluyendo a aquellos que han usado anteriormente las denominaciones de "Huancho" y "Puerto Viejo" o, simplemente, la de cerámica "Tardía". Sin embargo, es claro que aún subsisten bastantes vacíos en las secuencias propuestas o la muestra en estudio ha sido pequeña y circunscrita a un solo sitio. Entre los investigadores que han efectuado los más significativos aportes al tema 
de la cerámica Ychsma o sus afines, se pueden citar a Uhle, 1903; Strong \& Corbett, 1943; Bonavia, 1959; Iriarte, 1960; Feltham, 1983; Engel, 1984; Bazán, 1990; Paredes \& Ramos, 1994; Franco, 1998; Díaz \& Vallejo, 2002.

Si partimos de la información arqueológica conocida, en torno a la cerámica hallada en los valles bajos del Lurín y del Rímac (en términos cronológicos y culturales), resulta determinante, en primer lugar, el poder establecer sus parámetros dentro de un marco temporal y espacial. El lapso de tiempo comprendido entre los horizontes Huari e Inca enmarcan los rangos de actividad del estilo Ychsma, aunque es fundamental entender correctamente sus raíces u orígenes a finales del Horizonte Medio y su vigencia durante el periodo Inca.

\section{1. Distribución geográfica}

Los reportes arqueológicos que indican la presencia de cerámica del estilo Ychsma coinciden en ubicar a ésta en la región costera de los valles del Rímac, Lurín y la quebrada de Chilca. Aun en estos valles la distribución de la cerámica Ychsma se encuentra mayormente restringida al área de los valles bajos y parte de las primeras elevaciones andinas; se puede decir que la zona conocida como la chaupiyunga constituye su límite hacia el este. Comparativamente se trata de un área pequeña para la consolidación de un ente político centralizado y con posibilidades de excedentes productivos capaces de generar una expresión cultural propia y consistente en el tiempo. Es necesario, sin embargo, señalar que ésta es una de las características principales del área andina en su conjunto y en particular de la costa peruana, donde prácticamente existe una "cultura" específica por cada valle.

En este espacio o territorio Ychsma también está comprendida el área de lomas que se extiende a ambos lados de estos valles y que, de por sí, constituye un área sumamente extensa en términos espaciales, aún mayor que la de los valles mismos. Además, existen varios ecosistemas propios del litoral que posibilitan otras áreas de ocupación, como son las caletas intermedias y especialmente las áreas de humedales o pantanos. La isla de San Lorenzo también registra evidencias de ocupación humana (Isla, 1995; Hudtwalcker \& Pinilla, 2004), especialmente del periodo Ychsma e Inca, lo que indica claramente una intensa ocupación de todos los ambientes geográficos existentes y con posibilidades de aprovechamiento humano.

Aun teniendo como eje económico de la sociedad Ychsma las actividades agrícolas de los valles bajos logradas mediante un complejo sistema de riego a partir de canales hidráulicos de derivación de los ríos, es claro que el espacio susceptible de ocupación humana es mayor que el que representa únicamente el área cultivable en cada valle. Esta situación posibilita el establecimiento de mayores asentamientos en este territorio, y por consiguiente, una mayor población. De hecho, actividades como la pesca y el marisqueo incrementan significativamente las posibilidades de alimentación con su gran aporte proteínico, lo mismo que las actividades de ganadería de camélidos desarrolladas en las lomas vecinas o mediante el aprovechamiento del forraje de las áreas cultivadas en los valles bajos. 
Con todo, varias interrogantes surgen a este cuadro, en especial en el área del bajo Chillón, donde la cerámica ha sido apenas descrita y aún no se ha aclarado la presencia de la cerámica Chancay; incluso la situación de la banda derecha del Rímac es casi desconocida. Por el sur, en el valle de Mala, tampoco es clara la presencia del material cerámico y más bien parece ser ésta una zona de contacto e influencia con el grupo Huarco de Cañete. El material cerámico que Kroeber (1926) presenta como Late Cañete para la zona de Cerro Azul y el bajo Cañete, de hecho pertenece a otra tradición cerámica diferente a la de Ychsma y solo pareciera tener cierta relación o semejanza con algunos tipos cerámicos de la fase Ychsma Temprano B, en la secuencia aquí propuesta.

Conviene precisar que en época del Imperio Incaico, la cerámica Ychsma (fase Ychsma Tardío B) aparecerá en una mayor extensión de territorio que la que presentaba anteriormente, excediendo los límites del territorio clásico Ychsma como en Ancón (Ravines \& Stothert, 1976) (1) y en puntos de mayor altura en los valles, como el caso del sitio de Nieve-Nieve (Negro \& Fuentes, 1989) en el Lurín.

\section{2. Tecnología y producción de la cerámica Ychsma}

Por lo general, las características tecnológicas de la cerámica son bastante simples y básicas. Las formas principales son obtenidas mediante el modelado, aun en los tipos cerámicos más recurrentes, como también en los especímenes escultóricos o con apliques escultóricos. La gran variabilidad de los tipos cerámicos Ychsma y de los especímenes cerámicos se debe fundamentalmente a las características específicas de cada artesano o de cada taller en general.

Los tipos o especímenes cerámicos obtenidos mediante la técnica del moldeado son prácticamente desconocidos en las fases Temprana y Media de la secuencia Ychsma y solo llegan a hacerse relevantes en la fase final de la misma, correspondiente con el Horizonte Tardío (fase Ychsma Tardío B). En la fase Tardío A, sin embargo, comienzan ya a presentarse casos de uso de moldes, especialmente en pequeñas figurinas y en algunos apliques escultóricos.

Tipos de Pasta: Como criterio básico de clasificación de pastas hemos usado los componentes constitutivos de la misma, empezando por el componente principal de la cerámica: la arcilla. De esta manera, los principales tipos de pasta en la cerámica Ychsma son correspondientes, a su vez, a tres zonas geográficas particulares desde donde se obtiene la materia prima, es decir, la arcilla. Cada una de estas zonas presenta componentes arcillosos específicos, que establecen las características más evidentes de los tipos de pasta, como el color y la consistencia. Los materiales no plásticos, como los temperantes o desgrasantes adicionados intencionalmente en cada tipo de arcilla, también aportan mayores características a la pasta que generarán a su vez, variantes o subgrupos dentro de cada tipo principal.

La sociedad Ychsma hizo uso de los bancos arcillosos que existían en su entorno propio, es decir, en la franja litoral, las lomas y las quebradas inmediatas. En cada una de estas zonas,

(1) Si bien Ravines denomina como "Huancho" al material cerámico hallado, no cabe duda que estas piezas se inscriben en el corpus cerámico Ychsma para su fase más tardía. Además de dos especímenes "Huancho" (uno de los cuales es claramente del estilo Ychsma), también se hallan asociados a este contexto funerario una figurina femenina de cerámica en estilo Ychsma y dos piezas del estilo Inca Regional. 
la arcilla presenta características muy particulares debido principalmente a la procedencia geológica y demás factores intempéricos que han afectado los yacimientos arcillosos existentes. El tipo de pasta es, bajo este aspecto, un excelente indicador de la procedencia del material cerámico y de los talleres involucrados en su proceso.

Veamos los tres principales grupos:

Tipo A: también la hemos denominado del tipo Litoral. Este tipo de pasta emplea los bancos arcillosos existentes en la franja litoral caracterizada por las grandes terrazas aluviónicas o conos de deyección que se han formado en la parte baja próxima al mar, en torno a los cauces de los ríos. Estos bancos arcillosos se presentan generalmente en estratos o capas bien definidos. Su formación se debe al periodo de derretimiento de los glaciares alto andinos que produjeron corrientes de agua en la costa y formaron las terrazas aluviales costeña a manera de conos deyectivos. Este tipo de arcilla, llamada también arcilla de corrientes o arcillas diluviales, es de grano fino, se encuentra bastante impurificada por varios materiales erosionados y arrastrados a su vez por la corriente y que, por el tipo de partícula, también de grano fino, suelen depositarse junto con la arcilla. Entre estos materiales se encuentran principalmente la arena y otros componentes minerales como la cal y sustancias ferrosas (2).

A nivel macroscópico, la pasta del tipo A o Litoral es de color rojizo claro o anaranjado. Presenta numerosas inclusiones calcáreas de color crema y de arena de grano fino. Tienen por lo general poca consistencia y alto grado de porosidad.

Tipo B: denominada también del tipo Quebrada. Las arcillas de este tipo de pasta se originan en bancos arcillosos ubicados en las quebradas próximas a la costa. Son también yacimientos arcillosos formados en el periodo cuaternario por la erosión pluvial generada en las laderas rocosas próximas. Presentan un variado contenido de piedras, arena, gravilla, etc., depositadas junto a la arcilla por arrastre y por gravedad. El contenido de piedras puede ser eliminado mecánicamente y las más pequeñas generalmente se pueden mantener en la pasta o se hace previamente una trituración de las mismas a fin de homogeneizar y dar mayor plasticidad a la pasta.

A nivel macroscópico, la pasta del tipo B o Quebrada, es de color rojo, con numerosas inclusiones de piedras de grano pequeño. El contenido de cal (carbonato de cal) en estas arcillas suele ser mucho menor que en las arcillas del tipo A. Es de muy buena consistencia y de una porosidad mediana.

Tipo C: llamada también del tipo Lomas. Proviene de yacimientos arcillosos originados igualmente en los periodos glaciales del cuaternario y que se encuentran ubicados en las colinas próximas a las grandes terrazas aluviales costeñas. Estos yacimientos demuestran una gran exposición a diversos factores intempéricos, como la putrefacción vegetal (precisamente por el clima de lomas) y especialmente a la acción del oxígeno, transformando las inclusiones ferrosas. Su contenido de cal es casi nulo o muy pequeño debido a las permanentes infiltraciones de agua que han lavado progresivamente el carbonato de cal presente.

(2) La arcilla del tipo Litoral no es exclusiva de la región Ychsma, pues en realidad está presente en gran parte de las terrazas aluviónicas que forman los valles costeños. Por ejemplo, con fines comparativos se puede revisar los análisis efectuados por el Smithsonian Institution mediante el método de Scanning electron microscope + energy dispersive X-ray unit que reportan Shady \& Ruiz (1979: gráficos 1 y 3) para muestras cerámicas de Végueta (Huaura). Aunque en este caso, las muestras cerámicas pertenecen cronológicamente al Intermedio Temprano, son muy similares en los componentes minerales de la pasta de tipo Litoral utilizada por los alfareros Ychsma. 
A nivel macroscópico, la pasta del tipo C o Lomas, es de color marrón, con variantes claras y oscuras. Presenta buena consistencia y poca porosidad. Las inclusiones más usuales en este tipo de pasta son granos pequeños de cuarzo lechoso.

La preparación de la pasta: los procesos generales o básicos para la preparación de la pasta arcillosa comprenden variados niveles de actuación y de procedimientos, como la selección del material, su limpieza o retiro de elementos de impureza como las piedras y la arena gruesa, el tamizado o el lavado. Todos estos procedimientos serán claros indicadores del nivel de especialización del taller cerámico involucrado.

El procedimiento empleado también corresponde directamente a la función a la cual se destinará la vasija y en algunos casos éste guarda relación con determinado grupo cultural o época. Así, por ejemplo, en el periodo Inca, los tipos cerámicos decorados o de función no doméstica, aumentan proporcionalmente con respecto a los tipos domésticos, generando variadas vasijas de acabado fino, de formas escultóricas y que están empleando una preparación de la pasta muy cuidadosa.

Uno de los elementos más evidentes en la preparación de la pasta está en el empleo de materiales no plásticos, como desgrasantes. Entre estos están una serie de inclusiones de líticos diversos y que incluso brindan, en muchos casos, mayor consistencia y dureza a la cerámica. Estos líticos son también correspondientes a la zona de procedencia de la arcilla e indican el lugar de producción de los talleres cerámicos. Sus características, presencia y proporción generan varios subgrupos en cada tipo principal de arcilla.

Por ejemplo, existe un subtipo en la pasta de tipo A o de arcilla del tipo Litoral, que adiciona líticos laminares provenientes de la formación rocosa del Morro Solar. Su empleo está dirigido a vasijas de gran tamaño, como tinajones. En general la pasta del tipo A no adiciona líticos pues la presencia de la arena es suficiente como material desgrasante. Los casos en que se emplean se asocian con la función de la vasija que requiere de ésta mayor dureza. Otro subtipo, por ejemplo, emplea esta misma arcilla del tipo A con abundantes líticos de tamaño pequeño, a manera de gravilla o de arena gruesa, empleados en algunas ollas cerradas de la fase Tardío B.

La pasta del tipo B o Quebrada emplea preferentemente líticos de grano pequeño como la gravilla, en colores que varían del gris al negro y la mica.

La pasta del tipo C o Lomas, emplea preferentemente líticos de grano pequeño compuestos generalmente de cuarzo lechoso, pirita y algunos feldespatos.

En estos dos últimos casos, las variantes o subtipos están mayormente relacionados con la presencia y proporción de estos elementos líticos en la pasta arcillosa.

El Acabado: la mayoría de los casos incluso no emplean engobes, manteniéndose el color original de la arcilla. El alisado superficial suele ser bastante tosco. Éste debió ejecutarse empleando un trapo húmedo por las estrías que han quedado impresas en las superficies de las vasijas.

En pocos casos, se ha utilizado un pulimento de buen acabado y más bien éste ha dejado huellas del instrumento empleado, generalmente pequeñas piedras (cantos rodados) de superficie muy lisa que hacían las veces de pulidores. Este tipo de instrumentos se halla con bastante frecuencia en los basurales arqueológicos Ychsma.

La Decoración: para el decorado de las vasijas Ychsma, se han empleado varios métodos, la mayoría de ellos bastante simples, en especial en los periodos previos a la ocupación incaica. 
Los métodos más usuales son el punteado y las incisiones, aplicados a los especímenes que no utilizan la pintura. Este punteado debió hacerse con espinas dada la forma, grosor y profundidad del mismo.

La decoración pictórica está basada en cuatro colores básicos: crema, blanco, negro y rojo. Estos pigmentos son de origen mineral y se emplearon siempre pre-cocción. El color crema es uno de los más usados en la decoración Ychsma y se utiliza preferentemente para el relleno de los campos de diseño. Su composición mineral parece tener una base calcárea (obtenida muy probablemente en los mismos bancos arcillosos del litoral), la cual muestra grandes variaciones en la acentuación del color crema debido a las diferentes concentraciones del mineral en las preparaciones acuosas, notándose frecuentemente fluctuaciones entre el crema claro y crema amarillento (3). El color negro también se ha empleado frecuentemente en la decoración Ychsma y por lo general acompaña al crema como líneas de delimitación de los diseños. En el caso del color rojo, son pocos los especímenes que lo utilizan y, en general, se encuentran conjuntamente con ambos o alguno de los colores ya descritos. En cuanto al blanco, éste correspondería a un pigmento de origen distinto al crema, pues parece utilizar un mineral mucho más seleccionado que el crema; su utilización es muy escasa en la cerámica Ychsma.

Los casos de pintura post-cocción están restringidos a un tipo cerámico de la época Inca, de color negro pulido elaborado en ambiente reductor que emplea incisiones y estampados. Los colores post-cocción empleados son el blanco y el rojo ubicados al interior de las incisiones y como resalte de elementos escultóricos como los ojos.

En las fases Temprana y Media de la secuencia cerámica Ychsma, aparecen en la superficie de las vasijas, a manera de decoración, unas líneas bruñidas que algunas veces se entrecruzan entre ellas. El efecto de estas líneas, que resaltan con la superficie de la vasija mayormente áspera, se acrecienta cuando esta está mojada.

La Cocción: la cocción puede ser otro elemento de clasificación de la cerámica Ychsma y, por supuesto, se distinguen dos grandes grupos: los de ambiente oxidante y los de ambiente reductor. Al respecto conviene señalar que existen muy pocas evidencias arqueológicas sobre hornos cerámicos y, en general, sobre la manera específica de efectuar la cocción de la cerámica. Una visión general de la cerámica Ychsma demuestra que esta empleó preferentemente la cocción en ambiente oxidante y con bastantes casos de imperfección en la misma por la variabilidad de la temperatura. Los casos de sobrecocción (recochos) no son numerosos y creemos por tanto que, en promedio, se alcanzaban temperaturas mínimas para efectuar la cocción de la mayoría de piezas cerámicas Ychsma.

En el caso de las de ambiente oxidante y especialmente aquellas elaboradas con la pasta del tipo A, aparecen con frecuencia adheridas vitrificaciones de color amarillo verdoso en la superficie de las vasijas. Estas vitrificaciones son una clara evidencia del tipo y métodos de cocción empleado por la sociedad Ychsma. De hecho estas vitrificaciones solo se ubican en la parte externa de la vasija o en el borde y su presencia se debe al contacto con la arena al momento de la cocción cuando probablemente se superaban los puntos de fusión de la arena en puntos específicos del horno.

(3) De igual manera que en la cerámica de tipo Litoral, el pigmento de color crema empleado en la cerámica Ychsma, es muy similar —en la composición química y mineralógica — al de otras regiones costeñas como es el caso de Végueta. Los análisis efectuados por procedimiento idéntico al de la cerámica (ver nota anterior) a una muestra de pigmento del tipo Blanco engobado de Végueta (Shady \& Ruiz, 1979: gráfico 4) arrojan un alto índice de Calcio en este pigmento. 
El horno parece ser de tipo abierto y el método de cocción consistía en poner boca abajo las vasijas y cubrirlas con arena haciendo un pequeño montículo y luego quemar elementos combustibles sobre el montículo o en uno de sus lados en dirección opuesta al viento para que este avivara y dirigiera el calor hacia el montículo de arena que cubría las vasijas. Este método debe haber generado picos de calor así como bajas del mismo, sin embargo utilizándolo por un tiempo relativamente prolongado se lograría la cocción deseada. En algunos de los picos de calor al momento de la cocción, se ha debido producir la fundición de la arena que cubría las vasijas formándose así estas adherencias vítreas.

\section{LA CERÁMICA DE FINALES DEL HORIZONTE MEDIO}

Los trabajos de Dorothy Menzel (1968) han podido, en gran parte, clarificar el proceso y los estilos cerámicos inmersos durante el Horizonte Medio, también llamado período Huari, en particular aquéllos que se presentan en la región en estudio para la época $2 \mathrm{~A}$ y $2 \mathrm{~B}$. El trabajo de seriación y ubicación secuencial de esta cerámica fue hecho básicamente a partir de los materiales asociados a contextos funerarios Huari que halló Uhle en Pachacamac, Ancón y Nievería; a las colecciones de Baessler y Gretzer; al material que reporta Stumer procedente del sitio de Vista Alegre y también a entierros registrados por Marino González en Ancón. Gracias a ello podemos contar con una clasificación de los principales motivos iconográficos y morfológicos de esta colección, que incluso conforman, según Menzel, un estilo propio denominado por ella como "Pachacamac".

Un elemento de vital importancia, en cambio, está ausente en esta clasificación: la cerámica considerada doméstica o aquella no decorada que se asociaba igualmente con estos contextos funerarios y creemos importante, porque es en base a estas formas y técnicas de manufactura o decoración que se podría ver la convivencia de los estilos formales Huari con el estilo local inmerso en aquel periodo, como también con los tipos cerámicos que luego serán también la base para el desarrollo del estilo Ychsma. Un ejemplo claro de este elemento se puede apreciar con la situación del estilo Teatino en el valle de Chancay y en las necrópolis de Ancón, donde este estilo netamente local se asocia directamente con los estilos Huari de la época 2 (4).

Hacia las épocas 3 y 4 de Huari, de acuerdo con Menzel, las técnicas decorativas y de manufactura decaen fuertemente, utilizándose en los mejores casos solo los motivos iconográficos secundarios de la época 2 y que ahora se convertirán en los motivos principales o únicos en la decoración de las vasijas. El proceso parece generalizado en los Andes, especialmente en la costa, aunque hemos podido apreciar que éste no es uniforme a todos los valles costeños. La situación en las épocas 3 y especialmente la 4 parece más bien estar segmentada por varios procesos culturales independientes. Efectivamente, en las zonas de Ica y de Huaura, se configuran nuevos

(4) Aunque el estilo Teatino supera largamente la definición de cerámica doméstica, parece más bien haber gozado de gran popularidad durante el periodo Huari, a diferencia de algún estilo local en los valles de Lima y Lurín por ahora desconocido. Para mayor información sobre el estilo Teatino ver: Bonavia, 1962; Menzel, 1968; Villacorta \& Tosso, 2000. 
estilos de características propias y sumamente dinámicos, pues aunque compartan muchos elementos comunes a partir de sus orígenes en la época 2, son en esencia bastante diversos.

El estilo Huaura, del cual solo se han hecho escuetas referencias (Ravines, 1994) (5), toma su nombre del valle del mismo nombre ubicado al norte de Lima. Su presencia o influencia será también extensible a otros valles vecinos como los de Pativilca y Supe al norte de Huaura y a los valles de Chancay y Lurín al sur. En esencia este estilo parece recoger mucha de la iconografía de la época precedente, pero sus características tan propias y particulares hacen pensar de hecho en un distanciamiento religioso y cultural de los iconos precedentes Huari de la época 2.

La diferenciación estilística entre la época 3 y 4 no es del todo clara para el estilo Huaura, faltando por supuesto aun mayores precisiones al respecto, pues especialmente se carece de una seriación completa de este corpus cerámico. Sin embargo, en una investigación de este estilo y en estudios arqueológicos publicados donde aparece esta cerámica, las diferencias pueden ser reconocidas mayormente a nivel de la iconografía y de acabado. Un estudio preliminar de material de superficie en sitios Huaura, indica que en la época 3 predominan aún los motivos provenientes de la época 2, como motivos antropomorfos que hacen recordar al personaje de los báculos y otros elementos anexos, pero por supuesto con un tratamiento totalmente diferente. A nivel de pigmentos empleados y en detalles de los personajes o motivos tratados, el abandono completo o parcial de estos elementos precedentes de la época 2 es notorio. Aunque todavía permanezca un tratamiento de pulido en la superficie de la cerámica Huaura 3, ésta es cada vez menor en proporción con las formas que emplean un acabado mate. Con todo, para el estilo Huaura, la época 3 y comienzos de la época 4, parece ser la de su mayor expansión y prestigio, ya que durante finales de la época 4 es más evidente que en los valles vecinos se comienzan a adoptar nuevos elementos decorativos y morfológicos ya bastante diferenciados del estilo Huaura (6).

En su desarrollo, el estilo Huaura progresivamente irá dejando de lado casi todos los elementos que en un inicio le fueron comunes con la iconografía Huari, al punto de que más bien parece corresponder a una unidad cultural totalmente independiente (Fig. $1 \mathrm{a}, \mathrm{b})$. En cambio, la influencia del estilo Huaura para los valles vecinos, será tan fuerte que es a partir de este estilo que surgirán los estilos locales del Intermedio Tardío en cada

(5) Según Ravines (1994: 351), el estilo Huaura fue inicialmente tipificado por Rebeca Carrión Cachot. Material Huaura fue igualmente reconocido en las excavaciones que el Museo de Arqueología y Antropología y el Patronato de Arqueología efectuaron en Ancón desde 1945. Toribio Mejía Xesspe, en 1953 escribió el artículo "Cultura Huaura. Ensayo de interpretación sobre su origen y desarrollo", en el diario El Comercio de Lima (Dominical del 23 de agosto), detallando algunos elementos del estilo Huaura.

(6) Las variantes estilísticas al interior de la época 4, apreciadas tanto en la cerámica de Huaura como en la reportada pon Ravines (1981) para Ancón, hacen pensar en la existencia de dos momentos diferenciados o fases que podrían denominarse tentativamente como 4a y 4b. Existe además el hecho que los sitios arqueológicos asociados con esta época son numerosos en los valles de Huaura y Chancay, lo que hace pensar en una duración en el tiempo bastante larga. Un estudio más detenido de la época 4 del Horizonte Medio en la costa central, indica que ésta corresponde tanto a un periodo de gran complejidad social como a un periodo de evolución estilística bastante dinámico. 
uno de ellos, como el estilo Chancay y el estilo Ychsma respectivamente (ver Fig. 2). En el propio valle de Huaura, para inicios del Intermedio Tardío surgirá también un nuevo estilo cerámico diferente, que denominamos Huacho (7).

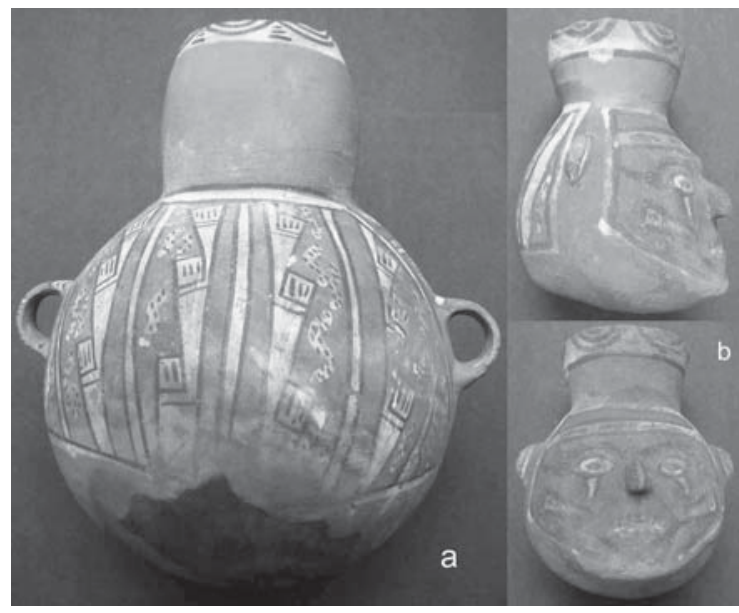

Fig. 1 - Cerámica del estilo Huaura H.M. 4. Végueta.

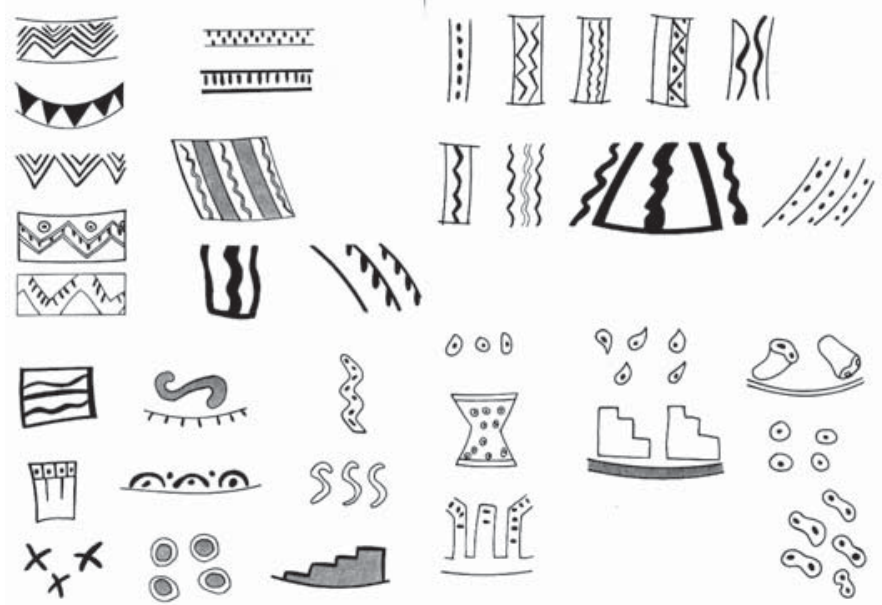

Fig. 2 - Diseños iconográficos de finales del H.M. 4. Pachacamac (Colección Templo Viejo).

(7) El valle del Huaura es un importante valle que hasta el momento ha sido poco estudiado, de hecho los inicios del Intermedio Tardío están caracterizados por una cerámica muy propia y única de este valle, diferente del anterior estilo Huaura y diferente también del estilo Chancay, por lo que creemos conveniente segregarla con la denominación de "Huacho". En los periodos Medio y especialmente en las fases finales del Intermedio Tardío, la cerámica Chancay se hará presente en el valle de Huaura en cantidades importantes, sugiriendo quizás una mayor preponderancia del valle de Chancay con respecto al de Huaura. 
Para finales del Horizonte Medio época 4, tanto en el valle de Chancay como especialmente en los valles del Rímac y del Lurín, el estilo Huaura comienza a desaparecer o sus formas básicas son de manufactura local con particularidades propias a cada zona. Aunque no conocemos la duración de esta época, pareciera configurarse como una compleja etapa de tránsito, donde bien pareciera considerarse por igual su pertenencia al estilo Huaura como a los nuevos estilos que surgirán en cada zona. En Chancay, muchas de las formas y motivos del estilo llamado "tricolor geométrico" (Horkheimer, 1970: 366a) serán la base para el estilo Chancay o también aparecen asociados con vasijas que exhiben únicamente los dos colores básicos de la decoración futura Chancay: el negro y el crema.

En los valles del Rímac y del Lurín el fenómeno es similar al del Chancay, aunque la muestra en estudio es mucho más pequeña, dado que, a diferencia del valle del Chancay y de la bahía de Ancón, en Lima y Lurín los sitios de esta época son muy escasos y en general pocoestudiados. Es cierto que mucho del avance urbano que ha experimentado Lima en los últimos años ha hecho desaparecer la mayoría de sitios arqueológicos alterando la muestra, pero la situación se repite en el valle del Lurín donde el avance urbano no ha sido grave.

De hecho, el único sitio que registra material de esta época, y en especial de esta fase, es el cementerio ubicado a los pies del Templo Pintado de Pachacamac, donde Uhle, durante sus excavaciones en 1898, halló numerosas tumbas de este periodo (Uhle, 1903) y en los hallazgos del Templo Viejo, realizados por Franco y Paredes (2000).

Tal parece, de acuerdo a las evidencias, que el valle del Rímac permanece en un nivel de depresión económica y poblacional en esta época, especialmente si tomamos en cuenta a la poca presencia de sitios asociados, a sus dimensiones y a los escasos reportes arqueológicos que evidencien material asociado cronológicamente (8). Aunque tanto el estilo Huaura como el Chancay inicial, son estilos netamente costeños, su presencia puede detectarse fácilmente en las partes medias de los valles correspondientes (9). En el caso de Lima y Lurín la presencia de material asociado con esta época, está casi restringido a la faja próxima al litoral. En el caso del valle bajo del Chilca, que se encuentra cercano al del Lurín, prácticamente se desconoce la presencia de material cerámico correspondiente con esta época (Engel, 1984), por lo que quizás la explicación para esta ausencia de material corres ponda a factores climáticos, teniendo en cuenta que Chilca es particularmente sensible a los periodos de sequía (10).

A diferencia de la situación en el Rímac y el Lurín, en los cementerios de Ancón, el material relacionado con finales del Horizonte Medio 4 es numeroso y variado. Mucho del material cerámico ahí hallado, obedece a un patrón estilístico hasta cierto

(8) Menzel (1968) ya lo había señalado anteriormente, pero correspondiente con la época 3.

(9) Incluso en el valle del Chillón, en el sitio arqueológico de Chocas, correspondiente geográficamente con las cercanías de la chaupiyunga, se han detectado restos de alfarería del estilo Huaura (Pérez \& Arce, 1989: 25); aunque siempre en escasa proporción.

(10) La secuencia cerámica en la parte baja del valle del Chilca es bastante correlacionable con las de Lurín y Lima para los periodos tardíos, por lo que los cambios en las fases cerámicas o la ausencia de determinada fase puede ser indicativa de procesos paralelos en los valles mencionados. 
punto constante, muy relacionado con los cánones estilísticos de Huaura (11). Las tumbas suelen ser bastante trabajadas, con elementos estructurales como los techados y con aditamentos en los fardos bastante representativos como las falsas cabezas.

\section{LA SECUENCIA DE LA CERÁMICA YCHSMA}

\section{1. La Fase Ychsma Temprano A}

Cuando tratamos el tema de la cerámica Ychsma ha sido siempre importante dilucidar su origen y las características de ésta. La tarea ha sido difícil considerando la escacez de información y sitios relacionados, sin embargo, creemos que el origen del estilo Ychsma se encuentra precisamente a finales del Horizonte Medio 4. Evidencias materiales de ello pueden detectarse en algunos de los estratos inferiores de Pachacamac, Armatambo y La Rinconada, aunque aún la muestra permanece pequeña. La asociación de estos estratos con un nivel específico de ocupación y de arquitectura no es del todo clara, impidiendo precisar elementos asociados. Este mismo material cerámico es, por el contrario, más abundante y claro en varios contextos funerarios hallados tanto en el Rímac como en el Lurín.

En el valle del Rímac, los contextos funerarios más claros y que pertenecen a esta misma época son los de Huallamarca, hallados en tumbas intrusivas a un montículo más antiguo. Reportes sobre estas tumbas aún no han sido publicados, pero la colección cerámica puede apreciarse en los depósitos de Huallamarca y Puruchuco. Casas \& Dolorier (2004, ms), recientemente han venido realizando estudios sobre algunos de los contextos funerarios de Huallamarca, en especial aquellos en que los individuos denotan pertenecer a funciones agrícolas o de textilería. En varios de estos contextos son apreciables elementos cerámicos pertenecientes tanto a finales del Horizonte Medio 4 (o fase 4B), como a comienzos del periodo Ychsma (fase Ychsma Temprano A).

En Pachacamac parece también ubicarse un importante cementerio de esta época, pero del cual solo se reportan noticias escuetas. Aparentemente Uhle, en sus excavaciones de 1896, encontró todo un nivel estratigráfico con estas tumbas, cuyo material asociado denominó como estilo "epigonal", pero solo registró las tumbas "tiahuanacoides" subyacentes (Menzel 1968) (12). En las láminas que acompañan la publicación de Uhle se pueden apreciar, sin embargo, algunas vasijas asociadas con los inicios del Ychsma Temprano A (Uhle, 1903: lam. 8 figs. 2, 3, 6).

Un hallazgo de excepcional relevancia, perteneciente también a esta época, se ha efectuado en Pachacamac durante las excavaciones efectuadas en el Templo Viejo, donde se ha descubierto un conjunto de vasijas escultóricas ofrendadas, en su mayoría representando animales marinos (Paredes \& Franco, 1989; Franco, 1993). Las características de manufactura y decoración de las mismas (Fig. 2), coinciden tanto con el inicio del estilo Ychsma, como a su vez con las características finales del estilo

(11) Ravines (1981), reporta varias tumbas de esta época, que el denomina "entierros de la época C'. Ver figs. 7316a, 7316b, 7375, 9632, 9644, 9646, 9733, 9958.

(12) Recientemente se han publicado algunas fotos de los trabajos de Uhle en Pachacamac (Kaulicke, 2001), donde se puede apreciar claramente la gran concentración de tumbas en ese sector, así como algunos elementos de la superposición estratigráfica entre ellas. 
Huaura. Elementos iconográficos y morfológicos similares con el Ychsma Temprano A han sido hallados a su vez en Ancón (Willey,1943: plate 1; Kauffmann, 1994: lams. 24 y 27).

En esta época, el tipo de morfología y decoración de la cerámica, de lo que hemos denominado Ychsma Temprano A (Fig. 3)(Uhle, 1903: lam. 7, figs. 4, 5, 6 y lam. 8 figs. $1,4)(13)$, se basa todavía en una gran diversidad de formas, tanto en los tipos decorados como no decorados. El uso de varios tipos de cuencos, platos, escudillas y vasos por ejemplo, lo relaciona directamente con la época precedente. Las variantes son más distinguibles especialmente en la decoración pictórica aplicada y a nivel de formas escultóricas, pues estas no alcanzan el nivel plástico de la época anterior. Una forma que comienza a hacerse más rara es la botella de doble cuerpo, muy popular en la época anterior (Fig. 3c). Están presentes también las botellas que incorporan un asa cintada en forma ovalada o curvada entre el pico y el cuerpo de la botella (Fig. 3d), así como las botellas de doble pico con asa puente (Franco \& Paredes, 2000: figs. 17, 18, 20, 21); estas últimas en una tendencia muy decreciente. Los picos de las botellas son generalmente altos, gruesos y de forma tronco cónica.

Los cuellos redondeados y convexos son frecuentes en esta fase, presentes en varios tipos de vasijas como pequeños cántaros y jarras (Fig. 3b, c). Otro tipo de cuellos altos y ligeramente convexos están presentes (Fig. 3a). Esta forma será en la siguiente fase muy común, pero ya sin decoración pictórica.
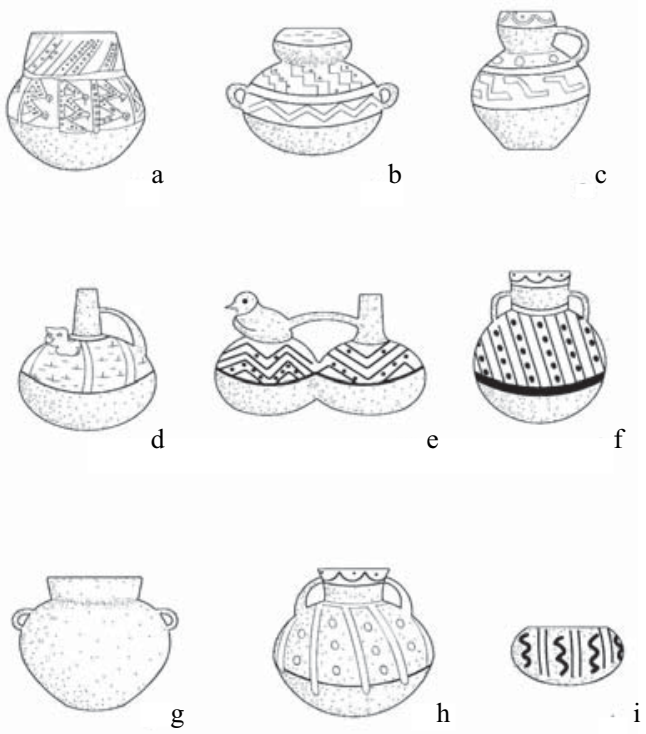

Fig. 3 - Formas cerámicas de la fase Ychsma Temprano A.

(13) De este grupo de vasijas, la única que continuara en la fase siguiente, al menos en la forma, será la № 5 . Todas las otras formas como platos, vasos y cuencos prácticamente desaparecerán. También ver Mason, 1969: fig. 28b. 
Los cántaros presentan generalmente un cuerpo globular algo achatado, con el gollete ligeramente evertido. Los labios adelgazados serán una de las constantes de esta fase. La decoración estará presente en el tercio superior del cuerpo de la vasija y en el cuello. Ésta consistirá en bandas oblicuas alternadas con puntos de color negro o blanco, o también en pequeños semicírculos con puntos negros en su interior, ubicados en los bordes de las vasijas (Fig. 3f, h).

Los colores usados son más limitados en esta época, restringidos a variantes de rojo u ocre, blancos, cremas y negro. La mayoría de estos colores son aplicados dejando espacios o el tercio inferior de la vasija con el color de la arcilla natural. El acabado es mayormente mate, desapareciendo de manera casi total los tipos de acabado pulido. Es notoria también una aplicación de la pintura un tanto descuidada o con claras huellas de imperfección, tanto en el trazo como en el relleno de los motivos representados (Purin, 1990: figs. 189, 190, 191).

\section{2. La Fase Ychsma Temprano B}

En la fase Ychsma Temprano B (Fig. 4), los cambios en la cerámica a nivel de la morfología y la decoración se muestran más drásticos que los cambios graduales experimentados en la fase precedente con respecto a las demás fases del Horizonte Medio. En general se percibe un abandono casi completo de muchos de los elementos de la fase anterior; solo en el aspecto morfológico, el abandono de formas clásicas como los cuencos, escudillas, platos, tazones y vasos es una constante. También en la decoración las variantes son importantes, pues el uso de colores se restringe fuertemente a apenas dos o tres colores básicos: crema, blanco y negro. En numerosos casos estos colores solo se aplican aisladamente, como el crema sobre la superficie natural de las vasijas.

El deterioro de la decoración pictórica, que en gran parte mantenía equivalencias y afinidades en la fase anterior con los valles del norte como el del Chancay y el del Huaura, será uno de los elementos más evidentes del cambio en esta fase. Coincidentemente, el proceso de manufactura cerámica tendrá también cambios relevantes, aumentando más bien los tipos cerámicos de acabado pulido especialmente en las vasijas elaboradas en ambiente reductor. En otros casos, para las de ambiente oxidante se emplea un fuerte alisamiento de la superficie con instrumentos o materiales que en muchos casos han dejado impresas las huellas del alisado. Las arcillas empleadas en varios casos son de color rojizo oscuro, como también frecuentemente de color rojo claro, correspondiente con las arcillas del litoral, estas últimas provenientes de lechos aluviónicos, más claras y con una fuerte presencia de arena de grano fino.

Un importante grupo morfológico surge en esta fase, predominando los contornos compuestos, en especial de los cuellos o golletes (Fig. 5). En algunos casos se añaden pequeños apéndices cónicos laterales, ubicados a la altura del cuello (Fig. 4d), en especial en la unión del cuello con el cuerpo, o en la parte media del cuerpo (Fig. 4d, h, k, 1, n, p) (Engel, 1984: plate 20 p. 4457; Paredes \& Ramos, 1994: figs. 22c, 22d, 26e, 26f, 33d; Franco \& Paredes, 2000: figs. 10 [segunda hilera], 15e, 15f). Estas formas compuestas se elaboran tanto en ambiente reductor como oxidante, pero la proporción 

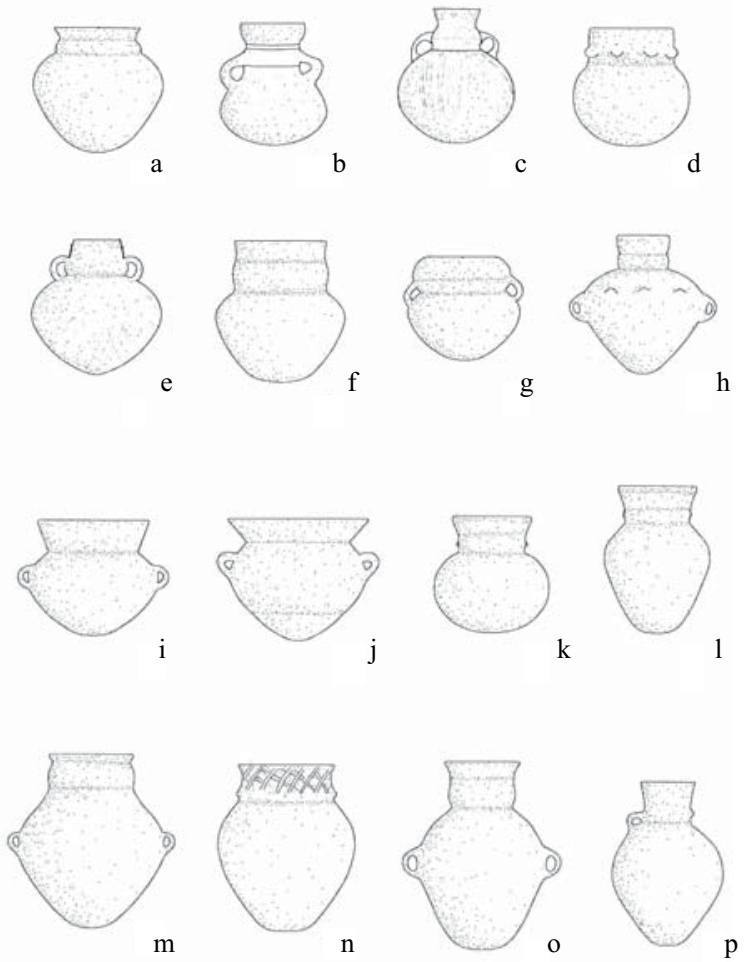

Fig. 4 - Formas cerámicas de la fase Ychsma Temprano B.

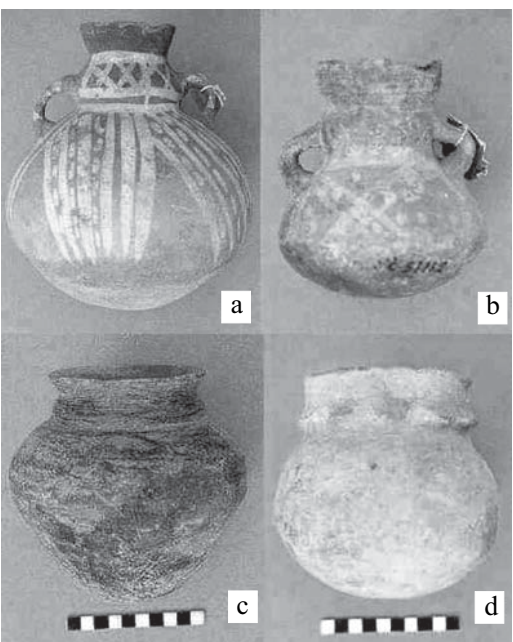

Fig. 5 - Cerámica de Macattampu perteneciente a la fase Ychsma Temprano B (MNAAHP - a: c-51156/MT3918; b: c-51112/MT80227; c: c-50564/MT3854; d: c-51735/MT4058). 
es bastante mayor para las de horno abierto. Con todo, las formas imperantes son siempre de cuerpo globular y de cuello alto, denotando fines utilitarios o domésticos en casi todas ellas. Destacan particularmente algunas vasijas con cuerpo cónico y las bases planas o ligeramente convexas (Fig. 5c).

Las formas escultóricas son sumamente raras y entre los pocos elementos decorativos que se adicionan a las vasijas están una serie de líneas bruñidas que se entrecruzan entre ellas (Fig. 4e, n) (Franco \& Paredes, 2000: figs. 10, 15 -solo la fig. $15 \mathrm{j}$ corresponde a la fase Medio A-), o simples diseños en color crema, como puntos o líneas que se entrecruzan (Figs. 5b; 4 b, c); algunas aplicaciones pictóricas recuerdan todavía algo de la decoración de la fase anterior (Fig. 5a). Las ollas presentan muchas veces el cuello recto y largo, bastante divergente (Fig. 4i, j) (Paredes \& Ramos, 1994: fig. 23 -inferior derecha-; Franco \& Paredes, 2000: fig. 15c). Un tipo de vasija muy típica de esta fase corresponde a un cántaro de cuerpo globular, cuello recto ligeramente convergente y de labio adelgazado (Paredes \& Ramos, 1994: fig. 43e).

Las jarras son también típicas de esta fase, y éstas, en general, son de gran tamaño (Fig. 4p) (Franco \& Paredes, 2000: figs. 15g, 15h). Aparecen varios tipos de ánforas, que también son generalmente de grandes dimensiones (Fig. 4o) (Franco \& Paredes, 2000: fig. 15f).

Contextos arqueológicos donde se han hallado especímenes pertenecientes al Ychsma Temprano B, son Armatambo; La Rinconada; Huallamarca, Pachacamac y Macattampu (14). En Huallamarca, Casas \& Dolorier (2004) reportan algunos contextos funerarios que podrían estar relacionados directamente con esta fase. En La Rinconada (Díaz, 2002), el material ha sido hallado dentro de estratos arqueológicos pero restringido a solo fragmentería; en Pachacamac en cambio el hallazgo corresponde a ofrendas de vasijas ubicadas en la parte superior del Templo Viejo (Franco, 1993: foto 4) y algunos contextos funerarios. Es muy probable que el gran cementerio de Pachacamac ubicado frente al Templo Pintado contenga numerosas tumbas de esta fase, a juzgar por los reportes de Uhle (1903) y por algunas fotos de la época que evidencian este tipo de vasijas. En el Museo de Sitio de Pachacamac, existe un grupo de ceramios pertenecientes a esta fase y que han sido catalogados como provenientes del sector de Puente Lurín.

Los materiales más numerosos por el momento, se encuentran asociados con contextos funerarios, hallados en Armatambo (Pérez, 1997), Huallamarca (Casas \& Dolorier, 2004) y principalmente en Macattampu (Tello, 1999), sitio hoy completamente desaparecido.

\section{3. La Fase Ychsma Medio A}

En las dos fases que componen el periodo Ychsma Medio, el estilo Ychsma adquiere sus formas más clásicas y reconocibles como propias. En general, durante el Ychsma Medio A, algunas de las formas compuestas de la fase anterior se continuarán

(14) Aunque aún faltan publicarse los recientes trabajos arqueológicos en Cajamarquilla donde se muestre el material cerámico asociado, pensamos que muchos elementos cerámicos hallados en este sitio y que son considerados genéricamente como "tardíos" podrían pertenecer a esta fase. 
fabricando pero en escasa proporción, surgiendo más bien los tipos cerámicos llanos, que algunas veces incorporan figurines modelados en el cuello o en el cuerpo de la vasija (Fig. 6); o aquellos que presentan decoración pictórica, estampada, bruñida o incisa. Los especímenes decorados siempre constituirán una muestra menor dentro del corpus cerámico de esta fase, pues la mayor proporción la constituyen formas globulares de contorno simple, sin mayor decoración pictórica o modelada, como ollas y cántaros (Fig. 7d, e, f, g).

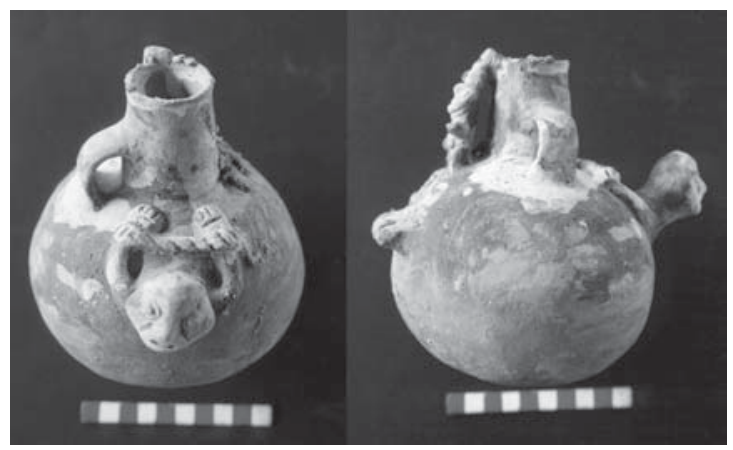

Fig. 6 - Botella con aplicación escultórica de finales de la fase Ychsma Medio A. Armatambo.

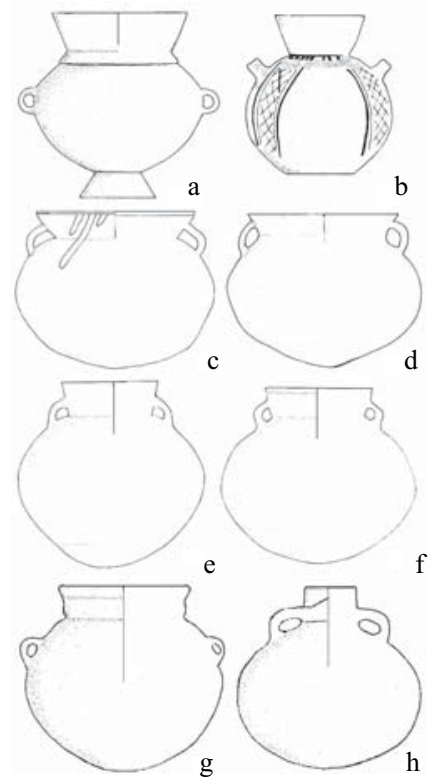

Fig. 7 - Formas cerámicas del Ychsma Medio A. Armatambo. (Díaz \& Vallejo, 2002). 
Se vuelven comunes las formas de gran tamaño, como cántaros, tinajas y tinajones de base convexa y contorno simple. Algunas de estas vasijas tienen el cuello recto o ligeramente convergente, con una depresión o rebaje adicional cerca del labio (Fig. 8h) (Paredes \& Ramos, 1994: fig. 18a, 32b, 38c; Eeckhout, 1995: fig. 15c; Díaz \& Vallejo, 2002: formas 26 y 41) o cuellos ligeramente combados que, en algunos casos, se presentan bastante divergentes (Eeckhout, 1995: fig. 15d; Díaz \& Vallejo, 2002: formas 35 y 36). Algunos cántaros o tinajas de esta fase se presentan con frecuencia con el cuello largo, las paredes rectas y divergentes, donde igualmente se utiliza el labio adelgazado o con rebajes cerca del cuello (Figs. 8b, c) (Paredes \& Ramos, 1994: figs. 30, 31; Díaz \& Vallejo, 2002: formas 22 y 23 ).

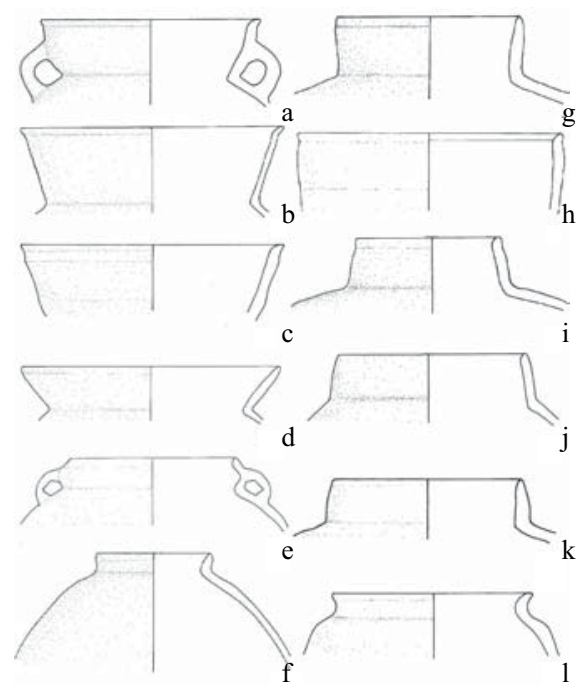

Fig. 8 - Cerámica de la fase Ychsma Medio A (Díaz \& Vallejo, 2002).

También surgirá un tipo de tinaja sin cuello que aplicará un borde oblicuo en forma de T, con la única decoración de líneas gruesas de color crema cerca del borde (Díaz \& Vallejo, 2002: formas 38) y pequeños apéndices cónicos en altorrelieve cerca del borde o también pequeñas asas de función decorativa (Díaz \& Vallejo, 2002: formas 38 y y 38 b). En casos raros se reproducirán diseños geométricos en color crema sobre la superficie natural.

Es usual durante esta fase, hallar contextos intrusivos en el terreno que se componen principalmente del entierro de gran cantidad de fragmentería cerámica, tanto en hoyos simples como en pequeñas estructuras que reutilizan materiales constructivos provenientes de otras estructuras. En La Rinconada (Díaz, 2002) se han hallado varios de estos contextos pero su significado es por el momento desconocido (Fig. 9). 


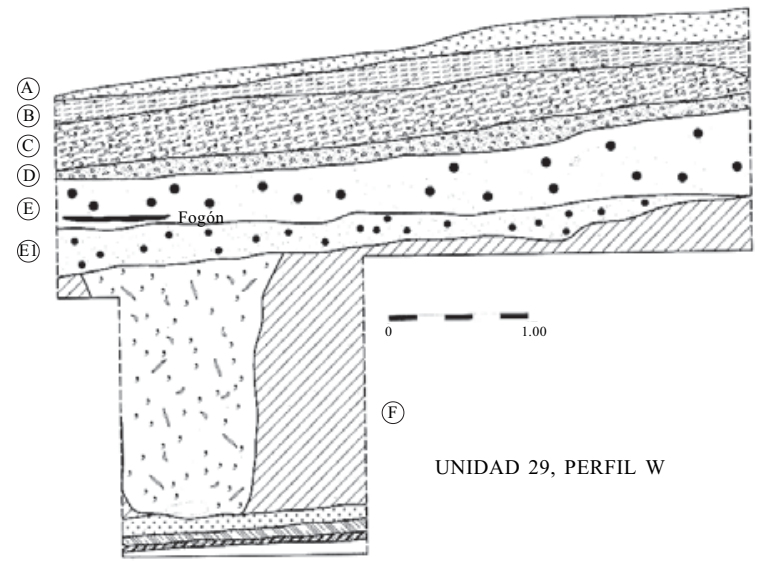

Fig. 9 - Perfil estratigráfico donde se aprecia un contexto intrusivo asociado con cerámica fragmentada. La Rinconada Alta (Díaz, 2002 ms).

En Chilca, Engel (1984) y González (2001) reportan un conjunto de formas y tipos cerámicos correspondientes geográficamente al valle medio y pertenecientes al estilo Cuculí, muy cercanos estilísticamente con los materiales del Rímac y Lurín para esta fase, predominando ahí también los cuellos altos, muchos de ellos de contorno en forma convexa algo grande, que pareciera formar todo un cuerpo adicional. Incluso sus fragmentos pueden llegar a ser confundidos con ollas o cuencos cuando en realidad solo constituyen el cuello de grandes cántaros (Engel, 1984: plate 7 p. 4409, 4334 y plate 6 p.4645, 3916; Franco, 1998: lam. 39 figs. 4, 5) (15) o de vasijas más pequeñas, pero con el cuello compuesto igualmente convexo y protuberante, que semejan una "tulipa" (Díaz \& Vallejo, 2002: forma 3). La decoración pictórica está prácticamente ausente en casi todas estas formas, salvo en especímenes muy particulares y escasos (Paredes \& Ramos, 1994: fig. 42b; Díaz \& Vallejo, 2002: forma 3a). En el caso de Chilca, estas formas presentan muchas veces una decoración en base a círculos estampados (16), pero en el caso del Rímac (área del valle bajo y litoral), estas formas son por lo general completamente llanas, con algunos casos menores de vasijas elaboradas en ambiente reductor.

(15) Schmidt (1929) publica una vasija escultórica muy rara, hallada en Pachacamac que, al parecer, pertenece a esta fase y en donde se aprecia a un personaje cargando a las espaldas precisamente uno de estos cántaros. Este personaje presenta una nariz "ganchuda" bastante pronunciada.

(16) Este tipo de cerámica que reporta Engel para Chilca y que denomina estilo Cuculí, presenta casi siempre una pasta de color marrón con temperantes de cuarzo, en un grupo muy similar al que denominamos pasta tipo Lomas. La decoración en algunas de estas vasijas con círculos estampados es semejante técnicamente a la que Krzanowski (1991) reporta para Chancay y denomina tipo Lauri impreso. Algunos investigadores ven en este tipo de cerámica influencias e incluso procedencias serranas; sin embargo este grupo cerámico parece tener más relación con los grupos de lomeros afincados en los valles medios de las vertientes occidentales, los cuales comparten elementos comunes en prácticamente todos los valles de la Costa Central. Hay que tener presente que en realidad, la comunicación de estos grupos era más bien en un sentido paralelo al del litoral, en un eje norte-sur, a través de vías y senderos hoy olvidados, pero que hacían que los diferentes ecosistemas de lomas se 
En los primeros momentos de esta fase, Ychsma Medio A, no es inusual el hallazgo de especímenes provenientes de Chancay, valle que ahora reemplaza en grado de influencia al que anteriormente ejercía Huaura. Sin embargo, el tipo de influencia debe haber sido quizás esporádica o restringida a pocos elementos que por lo general se limitan a pequeñas botellas (Fig. 7b), pues formas muy comunes en Chancay como platos, cuencos o vasos son prácticamente desconocidos en esta fase. En los contextos funerarios Ychsma, por ejemplo, los mates reemplazan siempre a estas formas cerámicas.

El tipo de decoración pictórica es quizás el rasgo más notorio de esta fase Ychsma, siendo comunes las vasijas que emplean únicamente el color crema en acabado mate como elemento decorativo, pero aplicado solo alrededor del cuello, el tercio superior o en los bordes (Fig. 7c), de una manera tan peculiar como descuidada que ha sido denominado como tipo "crema chorreado" (Díaz \& Vallejo, 2002: fig. 7a). La aplicación del color crema se presenta muchas veces de forma aleatoria a manera de toscos "brochazos" o en el mejor de los casos, en simples líneas gruesas (Díaz \& Vallejo, 2002: fig. 4).

En algunos tipos cerámicos la decoración pictórica muestra un mejor tratamiento cuando se trata de representar diversos motivos. Estos, sin embargo, se restringen tanto a diseños geométricos como reticulados (Bazán, 1990: lam. 2, fig. 610; Díaz \& Vallejo, 2002: fig. 3 v. 4) o líneas zigzagueantes; puntos o semicírculos. Precisamente en algunas vasijas, se ubican alrededor del borde una serie de semicírculos concéntricos como una forma decorativa típica de esta fase; aunque este diseño en particular provenga de fases anteriores (17). Los trazos de todos estos motivos se realizan siempre en color negro sobre un fondo crema, por lo que se le ha venido denominando como "negro sobre blanco". Toda esta decoración se aplica únicamente sobre los dos tercios superiores de la vasija, dejando el tercio cercano a la base solo en el color natural de la arcilla o ligeras aplicaciones aguadas de engobe de color marrón claro.

Son algo frecuentes también las vasijas donde la decoración consiste en líneas incisas zigzagueantes que describen pequeños triángulos o líneas incisas paralelas y

encontrasen íntimamente ligados a partir de las áreas intermedias entre los valles y quebradas occidentales. En algunos planos antiguos puede aún verse estas antiguas rutas de arrieros y lomeros que interconectan en un enorme espacio todos estos valles.

González (2001) en un interesante estudio de campo, define una predominancia geográfica del estilo Cuculí en el valle medio de Chilca y en las quebradas paralelas como la de Parca. Sitios importantes reportados en este estudio, con presencia abundante de material Cuculí, como Chichacara y Cuculí, se ubican respectivamente a los 1450 y 1200 msnm, además de un gran número de sitios arqueológicos menores distribuidos a lo largo del valle medio y de las quebradas adyacentes, hoy bastante áridas. Las formas cerámicas principales, que componen el estilo Cuculí, están distribuidas funcionalmente entre cántaros y ollas, que utilizan una pasta de color marrón mayormente con temperantes líticos de cuarzo, pirita, y líticos de color negro. Salvo el empleo de este tipo de pasta y el mayor grosor relativo de las formas cerámicas del estilo Cuculí, existen varios casos de semejanzas evidentes con formas cerámicas de igual función del estilo Ychsma (fases Medio A- B y Tardío A), indicando contactos frecuentes entre estos dos grupos culturales.

(17) En la fase Ychsma Temprano A es común el empleo de este diseño decorativo en los bordes de las vasijas. Incluso en el estilo Huaura de finales del Horizonte Medio 4, es usual su empleo. (Ver Fig. 1). 
que, al interior de estas se ha aplicado repetidamente un punteado fino (Fig. 10). Este tipo de decoración, conocida como "punteado en zona", se ubica con mayor frecuencia en ollas, alrededor del lado interno del cuello (Díaz \& Vallejo, 2002: formas 18b, 18c y 18d), aunque también se conoce su empleo en otros tipos de vasijas (18). Los especímenes que aplican el punteado en zona elaborados en ambiente reductor son desconocidos, dado que en general se aplica esta decoración en vasijas de horno abierto. Más bien se desarrolla un grupo cerámico escultórico, consistente en varios tipos de figurinas siempre modeladas, de formas antropomorfas o zoomorfas, destacando entre las formas antropomorfas la de representación femenina, con los rasgos y detalles resaltados con líneas incisas y/o punteados en zona (Engel, 1984: plate 21 p. 4588).

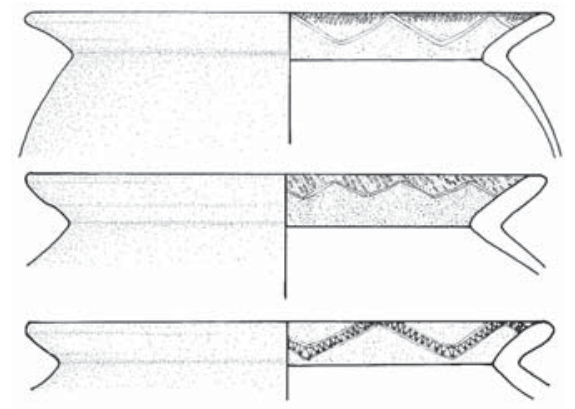

Fig. 10 - Decoración del tipo "punteado en zona". Armatambo (Díaz \& Vallejo, 2002).

Las formas típicas donde este tipo de técnica decorativa se presenta, son ollas de cuello abierto y varios tipos de figurinas, especialmente aquellas femeninas (también ver: Strong \& Corbett, 1943: fig. 19i; Eeckhout, 1995: fig. 15 a; Franco, 1998: lam. 39 figs. 1 y 2). Aparentemente todos los tipos cerámicos Ychsma donde se presenta este tipo de decoración podrían funcionar como un sub-estilo que convive con el estilo Ychsma. No conocemos especímenes que mezclen la decoración pictórica Ychsma con el punteado en zona.

Otras formas escultóricas parecen reducirse a pequeños y simples figurines zoomorfos, de factura tosca, siempre modelados y en donde destaca la representación de cuadrúpedos, que bien podrían tratarse de camélidos, perros o zorros. No se conocen elaboraciones de estas formas escultóricas elaboradas en molde (Engel, 1984: plate 21

(18) La decoración incisa y punteada pareciera tener sus antecedentes más reconocibles en una de las formas decorativas del estilo Teatino del Horizonte Medio 2 (ver: Bonavía, 1962; Franco, 1998; Villacorta \& Tosso, 2000). Sin embargo, las diferencias en la aplicación del punteado y de las incisiones entre ambos estilos es evidente. En las fases tempranas del estilo Ychsma es muy escasa su presencia, pues solo a partir de las fases medias su presencia comienza a ser relevante. Uhle reporta una pequeña jarra caragollete donde se puede apreciar este tipo de decoración incisa y punteada (Uhle, 1903: Lam. 8, fig. 9). 
p. 4617). En los casos que la representación modelada es antropomorfa, los personajes exhiben frecuentemente una nariz "ganchuda" y prominente, muy típica de los personajes de esta fase (Schmidt, 1929) (19).

En las vasijas que no presentan decoración pictórica o escultórica es usual el empleo de varias líneas bruñidas paralelas, que en algunos casos se interceptan entre ellas, causando un efecto decorativo en la superficie de las vasijas, dado que la superficie rugosa alisada contrasta con estas líneas bruñidas. El efecto se acrecienta cuando la vasija está mojada, lo que no es raro tratándose principalmente de botellas y cántaros donde este tipo de decoración bruñida se emplea.

En pocos casos se suele añadir un elemento escultórico zoomorfo o antropomorfo en uno de los lados del cuerpo de las vasijas a manera de aplicación modelada, donde los detalles del figurín son realzados con líneas incisas, punteadas o estampadas de pequeños círculos (Franco, 1998: lam. 39, fig. 3; Eeckhout, 1999: fig. 29).

Un rasgo característico de esta fase es el aumento de un tipo cerámico caracterizado por ollas medianas que adicionan un pequeño pedestal en su base y que pueden incorporar además decoración del tipo crema chorreado, aunque son muy comunes aquellos ejemplares que solo presentan la superficie natural (Fig. 7 a). En este tipo de ollas las asas son de forma cintada y de buena factura, siendo ubicadas en la parte media superior de la vasija (Bazán, 1990: lam. 2, fig. 483; Díaz \& Vallejo, 2002: fig. 4v, 8).

En cambio, en otras ollas menores (Fig. 7g), sin pedestal, con el cuello compuesto, de labio adelgazado evertido y cuerpo globular, las asas son muy pequeñas, tubulares y mal elaboradas, por lo general apenas adheridas al cuerpo de la vasija; éstas se ubican siempre en el tercio superior de la vasija o en la unión del cuello con el cuerpo de la vasija (Figs. 7e, f) y todo indica que su función es solo decorativa (Díaz \& Vallejo, 2002: fig. $7 \mathrm{~b}$ y formas 6,7$)$. Estos tipos de ollas, tanto las de pedestal como las ollas sin pedestal de cuello abierto como cerrado, serán una constante en esta fase y la siguiente, produciéndose muy pocos cambios entre ellas.

Morfológicamente, las vasijas de esta fase se caracterizan por las formas globulares y por presentar con frecuencia los labios adelgazados (Fig. 8) o con pequeños rebajes o depresiones decorativas cerca del borde (Figs. 8c, h). Un grupo de vasijas típicas de esta fase está constituido por cántaros de cuello recto, ligeramente combado y convergentes que provienen como tipo cerámico de la fase anterior, pero que en esta fase presentan el cuello más corto y el labio adelgazado (Figs. 8j, k). Algunas ollas, continuando de alguna manera con la tradición anterior, mantienen el cuello largo con las paredes rectas y bastante divergentes (Fig. 8d) (Paredes \& Ramos, 1994: fig. 43c; Díaz \& Vallejo, 2002: forma 17).

En los contextos funerarios es frecuente el hallazgo de pequeñas cantimploras de cuerpo lenticular y cuello angosto y alargado. Por lo general, es usual la aplicación de un poco de pintura de color crema y de apariencia acuosa alrededor del cuello (Franco \& Paredes, 2000: fig. 15j).

(19) Un textil proveniente de Pachacamac publicado igualmente por Schmidt (1929) y otro publicado por Uhle (1903) que se asocian al parecer con una de las fases Ychsma Temprano, también representan a cada uno de los personajes ahí diseñados con una nariz "ganchuda". 
Otros tipos cerámicos pertenecientes a esta fase pueden ser apreciadas en Paredes \& Ramos, 1994; y Díaz \& Vallejo, 2002.

\section{4. La Fase Ychsma Medio B}

En la fase Ychsma Medio B (Fig. 11) se desarrollarán los tipos cerámicos más reconocibles del estilo y donde las representaciones decorativas de las vasijas tendrán como elemento más recurrente los motivos de peces estilizados, puntos y las líneas zigzagueantes. Las formas cerámicas adoptarán muchas veces la forma modelada de una calabaza o un zapallo, especialmente en las botellas y cántaros medianos y pequeños (Fig.11 a, f). En algunas vasijas de cuerpo globular y cuello alargado, se le adiciona un pequeño figurín modelado antropomorfo, zoomorfo o fitomorfo según sea el caso, ubicándose siempre en la unión del cuello con el cuerpo de la vasija (Fig. 11d).
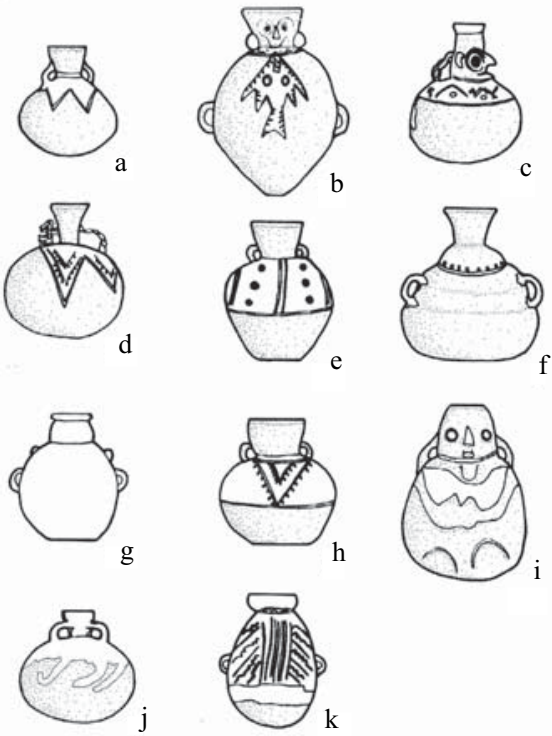

Fig. 11 - Formas cerámicas pertenecientes a la fase Ychsma Medio B.

Las formas cerámicas se vuelven más variadas, lo mismo que sus diversos elementos, como las asas y los cuellos. Las asas, por ejemplo, emplean la forma trenzada con bastante frecuencia (Fig. 11c, d). La decoración es también mucho más frecuente en estas nuevas formas, aunque el porcentaje de vasijas no decoradas sigue siendo importante, como las ollas. En estas, sin embargo es frecuente el encontrar la misma decoración de la fase anterior, en la forma de pequeñas líneas gruesas acuosas de color crema ("crema chorreado"), en el labio, el cuello o alrededor de las asas (Fig. 12c). La decoración del tipo punteado en zona y de líneas incisas se mantiene en algunas vasijas, pero su frecuencia es cada vez menor. Las figurinas en general continúan realizándose exclusivamente con la técnica del modelado y siempre con un acabado tosco. 


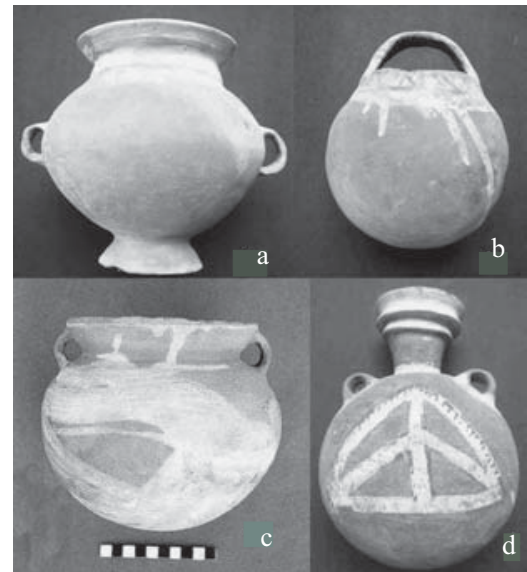

Fig. 12 - Cerámica perteneciente a la fase Ychsma Medio B. Armatambo (a, b, d) y La Rinconada (c).

Aumenta la presencia de jarras pequeñas, botellas (Figs. 12d;13a, b) y cantimploras en los contextos funerarios, así como la variedad de estas, sea en tamaño y forma como en los motivos pictóricos de su decoración. Los colores siguen siendo mate, aunque ya varias vasijas presentan más frecuentemente los alisados con un mejor acabado. Algunas formas incorporan adiciones escultóricas modeladas, sea en el cuerpo de la vasija como en el cuello; los motivos suelen ser zoomorfos como antropomorfos (Fig. 11c, i) con detalles que parecen asociarse con el personaje de los cántaros cara-gollete.

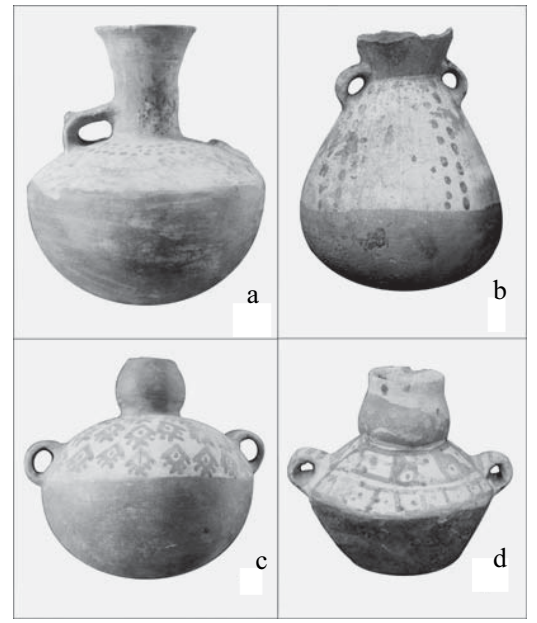

Fig. 13 - Formas cerámicas de finales de la fase Ychsma Medio B (a, b) y de la interfase entre las fases Ychsma Medio B e Ychsma Tardío A (c, d). Armatambo. 
En esta fase comienza a hacerse popular un tipo de decoración estampada o impresa, consistente en pequeños círculos hechos aparentemente con pequeños carrizos y que se ubican mayormente en el cuerpo de la vasija cerca de la unión con el cuello al cual circundan incluso en varias series. Por lo general, este tipo de decoración se presenta en las ollas medianas con pedestal u ollas de cuello corto cerrado. En este último tipo de ollas, las huellas de tiznado u hollín son frecuentes, denotando su carácter enteramente doméstico (20).

También en esta fase comienza a hacerse más constante el uso de vasijas medianas del tipo cántaro que incorporan un rostro modelado en el gollete o cuello, y que serán conocidas como vasijas "cara-gollete" (Fig. 11b). La particularidad de este tipo de vasijas hará que esta sea la forma más típica del estilo Ychsma, pues en ella misma se resumen muchos de los elementos plásticos que serán de uso en este estilo. El cuerpo de los "cara-golletes", será de forma cónica algo alargada, con aplicaciones de asa laterales cintadas ubicadas en la parte media del cuerpo. El cuello será mayormente evertido, con el labio redondeado y huellas o estrías del trabajo de alisamiento en el borde interno o externo. El tratamiento del personaje representado será a su vez tanto modelado como pictórico, haciendo que las manos, ojos, nariz y orejas se presenten especialmente en relieve. A menudo se representa escultóricamente una pequeña ave ubicada siempre entre las manos del personaje.

Los detalles escultóricos y otros elementos adicionales, como los brazos, el pectoral y usualmente un pez o varios motivos estilizados de ellos, se reproducen de forma pictórica. El interior de los brazos, como el del pectoral, se encuentra rellenado con pequeños motivos adicionales de tratamiento geométrico o diseños de peces muy estilizados. Los colores son los usuales del estilo Ychsma, es decir, fondo crema con diseños delineados en color negro, ambos colores en acabado mate. Los motivos representados pictóricamente son tratados en formas más redondeadas o curvilíneas, especialmente los de las facciones del rostro, ojos y peces del vientre. Los elementos escultóricos, como los ojos son globulares, sin mayores detalles adicionales y la nariz suele ser prominente; la boca del personaje se confunde con la unión del gollete y el cuerpo de la vasija (Hyslop \& Mujica, 1992: fig. 20). En algunos casos el rostro del personaje guarda mucha semejanza con el de un ave (Bueno, 1983: 26, fig. b).

Representaciones de rostros similares a los de estos cántaros, se ubicarán también, aunque de manera menos elaborada, en el cuello de algunas botellas pequeñas (Fig. 11c).

Un grupo de botellas medianas será bastante popular en esta fase, presentando el cuerpo de forma globular algo achatado, con la base convexa o cóncava, asas cintadas laterales y con el cuello angosto elaborado en forma de "tulipa", siendo esta particular

(20) Este tipo decorativo guarda bastantes elementos similares con aquéllos que son utilizados en la cerámica denominada Cuculí por Engel (1984) y reportada también por González (2001) para el valle medio de Chilca y Quebrada de Parca; así como también con el tipo o estilo denominado Lauri impreso por Krzanowski (1991) y reportado además por Cornejo (1992). En el caso de la cerámica Ychsma de la fase Medio B y especialmente en la siguiente, esta decoración está presente en ollas, todas ellas elaboradas mayormente con pastas del tipo Litoral, denotando su carácter y producción netamente local. 
forma de cuello, a veces de forma algo alargada. La superficie de estas botellas suele ser bien alisada o pulida, presentando siempre buena cocción. La arcilla empleada en este tipo de vasijas es por lo general de color marrón claro (Engel, 1984: plate 10 p. 2729, 2730). Algunos cántaros pequeños o botellas de cuerpo globular más redondeado, también utilizan este tipo de cuello en tulipa, pero este es de forma más redondeada. El acabado es algo más tosco y elaborado en arcilla natural de color rojo (Engel, 1984: p. 3940, 4291; Bazán, 1990: lam.1 fig. 521).

Otro tipo de botellas, de cuerpo globular algo achatado, bastante típico de esta fase (Fig. 11j), emplean una decoración pictórica alrededor del cuello, de líneas gruesas y simples de color crema (Paredes \& Ramos, 1994: fig. 21d y 48).

Una vasija típica de esta fase, es un tipo de cántaro de cuerpo globular y base plana, con el cuello o gollete recto y expandido, y con un par de pequeñas asas cintadas que se ubican en la unión del gollete con el cuerpo. La decoración de estos cántaros se ubicará invariablemente en la parte superior del cuerpo de la vasija y consistirá en líneas paralelas de color negro sobre fondo crema, a las cuales se les intercalarán varias series de círculos negros (Fig. 11e). A veces se recurre como motivo decorativo a líneas en V de color negro, igualmente sobre fondo crema (Fig. 11h).

En esta fase comienza a aparecer un tipo de cuello muy particular por su construcción, especialmente aplicado en vasijas destinadas a contener líquidos; este consiste en un cuello angosto y largo donde cerca del borde se le ha añadido una cinta suplementaria de perfil adelgazado. El borde es ligeramente expandido (Fig. 12d) (Engel, 1984: plate 16p. 4509).

Las formas consideradas domésticas conservan muchos de los elementos básicos de la fase anterior, como por ejemplo las ollas con pedestal (Fig. 12a). Las ollas simples de cuello abierto mantienen el cuerpo globular, los cuellos rectos y expandidos (que tienden a ser más cortos). Las asas presentan ligeras modificaciones en su conformación pasando de las tubulares a asas achatadas o medianamente cintadas (Machacuay \& Aramburu, 1998: fig. 9a). Las ollas cerradas mantienen igualmente el cuerpo globular y los cuellos altos ligeramente divergentes (Machacuay \& Aramburu, 1998: fig. 8c), o en el caso de los cuellos cortos presentan asas más consistentes en la unión del cuello con el cuerpo (Machacuay \& Aramburu, 1998: fig. 9b).

Las vasijas sin cuello, que al parecer funcionan algunas como pequeñas ollas, no son tan comunes y mantienen cierta frecuencia especialmente en los contextos funerarios. Varias incluso recuerdan la forma de un tipo especial de mates (Machacuay \& Aramburu, 1998: figs. 7c, 8a) o de pequeñas canastas (Fig. 12b).

Las tinajas y tinajones, muy comunes en los contextos pertenecientes a las fases Ychsma Medio, presentarán una construcción algo similar a la fase precedente, siendo más recurrente un tipo de tinaja cerrada sin cuello, con un grueso labio en T. Este tipo de tinajas presenta un par de asas pequeñas o pequeños apéndices cónicos, que se aplican cerca del borde, solo de función decorativa. Los cuerpos de estas vasijas son siempre de gran tamaño y de forma ovoide con base cónica-convexa. El acabado será siempre en color natural con algunos casos donde se aplica adicionalmente pintura de color crema en el borde, a manera de toscos brochazos (Bazán, 1990: lams. 17g, 27d-e). 
Aunque es poco frecuente, no es del todo raro encontrar en los contextos arqueológicos de esta fase, especímenes cerámicos pertenecientes al estilo Chancay, por lo general siempre restringidos a piezas pequeñas del tipo botella o principalmente destinadas a contener líquidos (Fig. 11k).

\section{5. La Fase Ychsma Tardío A}

Luego de la época Ychsma Medio, los cambios que se producirán en la sociedad Ychsma parecen ser de envergadura, percibiéndose modificaciones importantes en casi todos los órdenes culturales y tecnológicos. Muchos de estos cambios, son definitivamente anteriores al periodo Inca y están asociados además con un mayor dinamismo de la cerámica Ychsma. Los contextos arqueológicos de esta fase suelen ser más complejos y numerosos comparativamente que los de las fases anteriores. En sí mismo, estos contextos indican una mayor movilización de elementos culturales, de la cual la cerámica es un reflejo.

En la fase Ychsma Tardío A, aparecen varias nuevas formas cerámicas, pero manteniendo en gran parte los mismos cánones decorativos de la fase anterior. Por ejemplo, aparecen unos cuencos anchos, con contorno carenado o "aquillado", que incorporan los mismos motivos estilizados de peces en su decoración, o motivos geométricos como líneas paralelas, rectángulos y puntos en color negro. Tanto los colores usados, crema y negro, como la forma de aplicarlos es muy similar al modelo típico Ychsma, con un acabado mate. En algunos casos existen pequeñas aplicaciones modeladas laterales a manera de asas (Engel, 1984: plate 8 p. 4346; Paredes \& Ramos, 1994: fig. 40a, b, c; Franco, 1998: lam. 43, figs. 9, 10, 11, 12, 13 y lam. 46 fig. 20; Eeckhout, 1999: fig. 16b, c, d).

Tal vez un rasgo diferencial con las fases precedentes sea en el tipo del color crema empleado, pues este presenta notorias variaciones en su tonalidad, desde el crema claro, casi blanco hasta un crema verdoso. Estas variaciones son también acentuadas por la mayor y mejor cocción de las vasijas en esta fase (Fig. 14b).

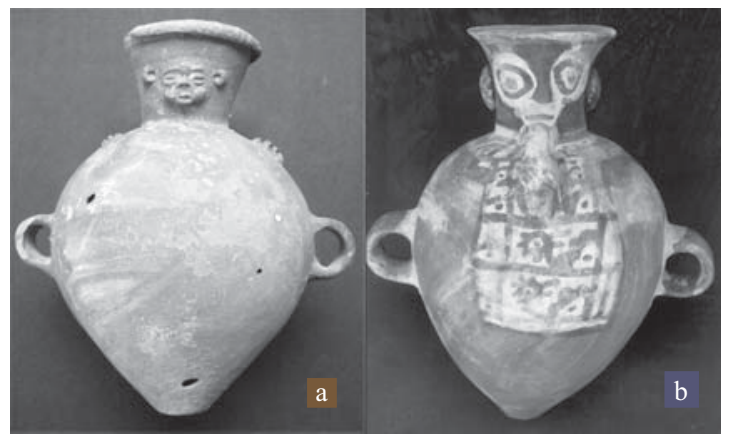

Fig. 14 - Cerámica perteneciente a la fase Ychsma Tardío A. Armatambo. 
Las vasijas decoradas en general comienzan a mostrar gran variedad, aunque siempre serán escasas en comparación del material no decorado. Estas vasijas decoradas, incorporan nuevos elementos plásticos, como el de acompañarse de figurines escultóricos, tanto en la unión del cuello con el cuerpo como en el cuerpo mismo, especialmente en figuras de monos, perros y felinos. Varias veces estos animales se encuentran tapándose el rostro con una de sus patas.

Un tipo de vasija que comenzará a ser común, es un cántaro de cuerpo globular, base plana o ligeramente convexa y cuello expandido. El asa cintada se ubicará entre la unión del cuello con el tercio superior de la vasija. El rasgo más destacado de este tipo de cántaros será la aplicación modelada de una figura escultórica representando a un cánido, en posición extendida y las extremidades desplegadas sobre el cuerpo de la vasija (Engel, 1984: plate 18 p. 4475).

Un elemento decorativo importante es la aparición de culebras o serpientes en la decoración, presentes a manera de adiciones escultóricas en las vasijas. El uso y posición de estas serpientes en esta fase es bastante libre, encontrándose variados ejemplos de su empleo en diversos tipos de vasijas.

Las formas domésticas como ollas y cántaros, también experimentan muchos cambios, lo cual es novedoso en la producción cerámica Ychsma, pues este tipo de vasijas en las fases anteriores son las de menor variabilidad. Las ollas por ejemplo emplean ahora las asas medianamente cintadas en unión del labio con el tercio superior del cuerpo (Engel, 1984: p. 4261; Franco, 1998: lam. 45 fig. 9).

Surge un nuevo tipo de olla, de cuerpo globular alargado, con el cuello corto, convexo y el par de asas horizontales, ligeramente alzadas (Fig. 15b). Este tipo de olla, más propia por su forma como un cántaro, se volverá bastante común durante el desarrollo de esta fase, encontrándose casi siempre con la superficie tiznada, como evidencia de su uso doméstico (Ravines, 1994: fig. 543) (21).
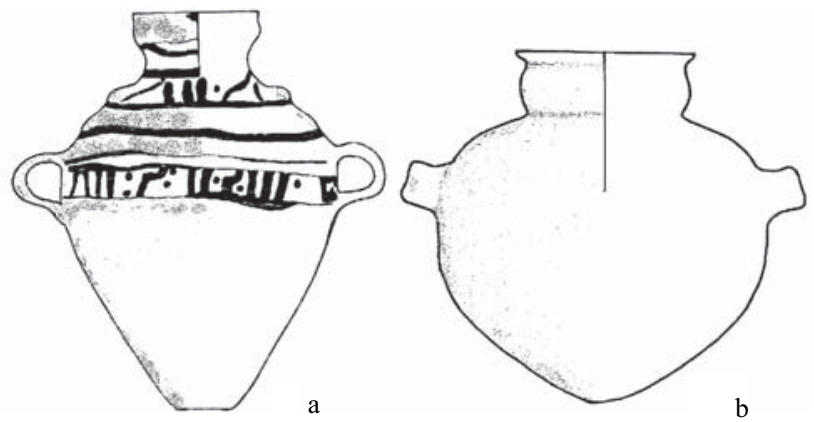

Fig. 15 - Formas cerámicas de la fase Ychsma Tardío A.

(21) Un rasgo notable de este tipo de ollas es que en la fase siguiente incorporará siempre la decoración escultórica de una serpiente ondulante ubicada en el cuerpo y que dará una gran variedad de formas paralelas. 
Aparece más recurrentemente un tipo de cántaro de cuerpo algo cónico, asas laterales cintadas y cuello de contorno compuesto, con el labio expandido y redondeado, elaborado siempre en un tipo de pasta particular que utiliza una arcilla de color marrón oscuro y temperantes líticos del tipo de cuarzo lechoso. El acabado suele ser en color natural sin adiciones pictóricas (Ravines, 1994: fig. 547).

Muchos de los cambios que se producen en esta fase, están distribuidos entre varias características tecnológicas o morfológicas que afectan a casi todas las vasijas. Las arcillas, hasta la fase anterior casi siempre locales, ahora comienzan a mostrarse más variadas, donde se percibe mayor movimiento de vasijas que están manufacturadas en otros talleres en base a arcillas y temperantes no locales. Los temperantes principalmente, más el tipo de arcilla empleada, son muy buenos indicadores de la procedencia de la vasija y de la zona geográfica donde se produjo. Así, los temperantes en base a piedra molida, como el granito, son más frecuentes en esta fase.

La cocción también experimenta cambios, pues en general las vasijas exhiben mejor cocción y con mayor temperatura, ya que los tipos con sobrecocción son más abundantes y especialmente aquellos que presentan vitrificaciones. Las vasijas elaboradas en ambiente reductor presentan un mejor acabado, incluso la superficie es pulida (Fig. $16 \mathrm{c})$.

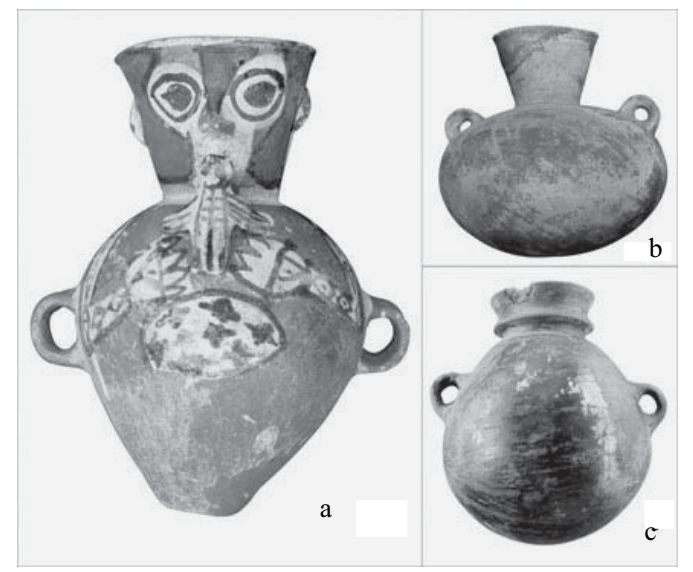

Fig. 16 - Cerámica de inicios de la fase Ychsma Tardío A. Armatambo.

Una de las vasijas que exhibe mejor elaboración es la del tipo cara-gollete, utilizando colores con mejor fijación a la superficie de la vasija, mejor cocción e incluso adiciones del color rojo con mayor frecuencia y distribución, especialmente en los diseños que constituyen el rostro del personaje (Figs. 14 b; 17) (Isla, 1995: fig. 6d; Díaz \& Vallejo, 2003b: fig. 3). El uso y frecuencia de este tipo de vasijas es mayor que en la fase anterior, existiendo incluso variantes locales como las de Chilca y Mala, donde son bastantes recurrentes para esta fase. Los cara-golletes de estos dos valles, muestran en general un buen acabado y se diferencian de los del Lurín y Rímac, por tener el cuello 


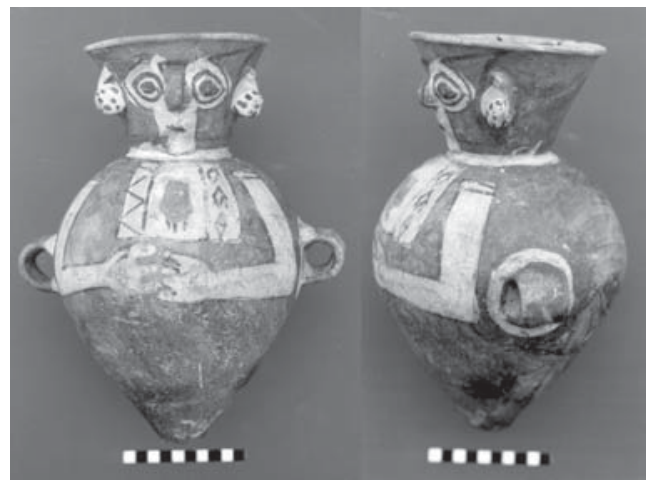

Fig. 17 - Cerámica del tipo "cara-gollete" de la fase Ychsma Tardío B. Isla San Lorenzo MNAAHP- N³358 / C-23338 (foto L. Díaz).

más recto o escasamente evertido. El labio suele mostrar un ligero adelgazamiento y es muy frecuente el uso del color rojo, además del crema y negro. En varios casos de Chilca, el personaje principal, como en el Rímac y el Lurín, aparece también besando el pico de una pequeña ave que se encuentra entre sus manos (Figs. 16a; 14b) (Uhle, 1903: fig. 83; Bonavía, 1959: lam. I; Engel, 1984: 4481, 4473, 4483), o como el caso de Mala, donde el ave es regularmente pintada de perfil en el cuerpo de las vasija.

Morfológicamente las vasijas incorporan o popularizan nuevos elementos, como los bordes biselados (Paredes \& Ramos, 1994: figs. 16g, 26c), las bases planas y los cuellos bastante expandidos. También es notorio un incremento de vasijas que aplican un grueso reborde en el labio, a manera de adorno suplementario, especialmente en las vasijas de cuello expandido (Engel, 1984: 3946; Paredes \& Ramos, 1994: fig. 16f). En algunas de estas vasijas con reborde, correspondientes a cántaros, se les suele agregar la aplicación de un rostro de facciones toscas y gruesas en el cuello o gollete (Fig. 14a). Entre los acabados aumentan los tipos cerámicos que presentan un engobe de color marrón, pero aplicado de manera tosca e irregular (Fig. 16b).

Existe un grupo de tinajas y tinajones que incorporan un reborde muy saliente de forma lenticular (Bazán, 1990: lam. 46; Paredes \& Ramos, 1994: fig. 45a). Este tipo de tinajas son casi siempre elaboradas en una pasta arcillosa de color marrón oscuro y son muy populares en la banda derecha del Rímac y en la zona del valle bajo del Chillón, aunque en esta fase y especialmente en la siguiente se hallaran con frecuencia en todo el valle bajo del Rímac.

Los motivos iconográficos son bastante similares con los de la fase anterior, reproduciendo estilizaciones de peces (Fig. 13c), escalonados (Figs. 13d; 15 a) o romboides (Bonavía, 1959: lam. IVa, b, c, d, g, h) y se concentran mayormente en los tipos cara-gollete y en los cuencos aquillados o pequeñas botellas.

\section{6. El periodo Inca}

Durante el periodo Inca las modificaciones que se producirán en la sociedad Ychsma serán de enorme trascendencia y no solo afectarán de manera aislada a diversos comportamientos culturales sino que se verán mayormente muchas incorporaciones 
tecnológicas a nivel de los artefactos y diversas manufacturas (Díaz \& Vallejo, 2003b; 2004). En los contextos arqueológicos de este periodo, la presencia de varios corpus cerámicos es clara y manifiesta, notándose una confluencia de variadas corrientes estilísticas y grupos alfareros.

Durante este periodo, el grupo cerámico principal parece estar basado en tres grandes corpus cerámicos que confluyen e interactúan entre ellos: el estilo Ychsma, el estilo Inca cuzqueño y el estilo Inca Regional. Tanto el Ychsma como el Inca, son dos estilos que se inscriben respectivamente cada uno de ellos, en una tradición anterior y propia; el estilo Inca Regional surge como una mezcla o "hibridación" de los dos anteriores y que a su vez recibe aportes importantes de estilos de origen norteño como el Chimú o el Chimú-Inca.

Además de las formas pertenecientes a los estilos Ychsma e Inca Regional, es algo frecuente hallar formas pertenecientes al estilo Chimú (Uhle, 1903: lam.13, figs. 9, 12), o del estilo Chimú-Inca (Uhle, 1903: lam. 18, fig.11; Hyslop \& Mujica, 1992: fig. 22; Isla, 1995: fig. 7b; Eeckhout, 1995: fig. 28c), lo que ha llevado a algunos investigadores a diversas interpretaciones, asociándolas la mayoría de ellos a la presencia de mitimaes provenientes de la costa norte peruana (22). Sin embargo, es notorio que estas vasijas son completamente diferentes, a nivel estilístico, al Ychsma Tardío y al Inca Regional. Incluso su producción es totalmente foránea a la región Ychsma, en especial la perteneciente al estilo Chimú. La presencia de muchas de estas vasijas puede deberse más bien, sin descartar la presencia de mitimaes, a niveles de intercambio o de tributación, elementos muy comunes durante el periodo Inca, en especial este último que parece determinante en gran parte de las correspondencias sociales que se dieron en este periodo. Es imprescindible por ello, un análisis definitivo de arcillas y pastas que identifique claramente los centros de producción alfarera en la región Ychsma para, a partir de ello, esclarecer la situación de los mitimaes y su implicancia en el desarrollo de la cerámica en la región para el periodo Inca.

Causa sin embargo extrañeza la poca o nula presencia de material o influencias de los estilos Chincha e Ica, a pesar de su gran calidad estética y plástica, lo cual los convertiría en elementos de prestigio y demanda. Tal parece que la relación con esta región sureña fue muy escasa o limitada a solo algunos pocos elementos culturales, hecho ya notorio durante todo el desarrollo del estilo Ychsma y que se repite también durante el periodo Inca.

En cambio, la presencia del material cerámico de estilo Inca es manifiesta y muy variada, presentándose en los contextos asociados todas las formas típicas del estilo

(22) Aunque Larco (1948: 54-57) comenzó a esbozar las formas cerámicas y las características generales del estilo Chimú-Inca, es poco lo que se sabe sobre el comportamiento de este estilo tan particular y en especial, los rangos de distribución geográfica y popularidad. Fuera del área nuclear Chimú, la presencia de material cerámico perteneciente a este estilo o asociado a él, se ha asumido como indicador claro de la presencia de mitimaes norteños. Al margen de este tipo de interpretaciones, es necesario profundizar en las características formales de este estilo e identificar los tipos y formas cerámicas del mismo. En general, muchos arqueólogos han rápidamente asignado como perteneciente a este estilo a todos los tipos cerámicos que presentan cocción reductora y acabado pulido; sin embargo, en la tradición cerámica Ychsma, estos elementos están también presentes en fases preincaicas. 
cuzqueño. Los aríbalos (Uhle, 1903: lam. 18, fig.1; Strong \& Corbett, 1943: fig. 7a, b, fig. 8f, fig. 9a, 10b; Eeckhout, 1995: fig. 8b; Isla, 1995: fig. 9; Franco, 1998: lam. 48, figs. 5 y 6; Eeckhout, 1999: fig. 26; Córdova, 2000: foto 188; Diaz \& Vallejo, 2003b: fig. 10), platos (Uhle, 1903: lam. 7, fig. 15 y lam. 18, fig. 6; Strong \& Corbett, 1943: fig. 7c, d, e y fig. 8a, b, c, d; Eeckhout, 1995: fig. 8a; Franco, 1998: lam. 48, fig.15; Diaz \& Vallejo, 2003b: fig. 11) y tazones (Uhle, 1903: lam. 18, fig. 3; Strong \& Corbett, 1943: fig. 9g, 12b; Engel, 1984: 3962, 3286, 4062; Silva, 1992: fig. 148; Isla, 1995: fig. 8; Franco, 1998: lam. 48 figs. 1 y 2; Córdova, 2000: foto 189; Makowski, 2003: fig. 8b; Díaz \& Vallejo, 2003b: fig. 12) son los más frecuentes en los contextos del periodo Ychsma Tardío B, pero es común hallar estas vasijas con otras formas cerámicas del mismo estilo Inca cuzqueño (Uhle, 1903: lam. 18 figs. 4, 5, 7; Guerrero, 1998: 105 y 106; Makowski, 2003: fig. 10d). Varias de estas formas, pertenecientes exclusivamente al estilo Inca cuzqueño y que son de uso doméstico muy particular, como las halladas por Uhle en Pachacamac (Uhle 1903: lam.18, figs. 4 y 5), denotan claramente la presencia de grupos de personas de este mismo grupo étnico, por la función cotidiana que en este tipo de vasijas está implícita. Fragmentería cerámica similar ha sido hallada a su vez en Armatambo, indicando también la presencia en el lugar de personas de origen étnico cuzqueño.

Incluso muchas de estas formas incaicas son de manufactura local, empleándose en efecto las arcillas y los pigmentos locales (Eeckhout, 1995: fig. 27; Makowski, 2003: fig. 10b; Diaz \& Vallejo, 2003b: figs. 9, 11, 12), o como en el caso de los pequeños platos que adicionan un apéndice a manera de asa representando el cuello y cabeza de una ave (Strong \& Corbett, 1943: figs 9b, 10a), que pueden llegar a ser manufacturados con las técnicas locales de cocción reductora (Strong \& Corbett, 1943: fig. 9d).

Es claro que la ocupación incaica fue intensa en esta región y la llegada de elementos cerámicos del estilo cuzqueño bastante usual. Los contextos arqueológicos asociados con este periodo presentan una significativa cantidad y variedad de elementos cerámicos del estilo Inca en tal grado que indudablemente la producción de la alfarería incaica fue generalizada.

Además de las formas típicas del estilo Inca, surgen nuevas formas y elementos decorativos, que bien pueden considerarse como mezclas del estilo Inca con el estilo local o como evoluciones propias de los tipos cuzqueños (23). La denominación de este tipo de vasijas es dificultosa debido a que ya se ha usado repetidamente el término de Inca Provincial con varias significaciones, por ello preferimos denominarlas Inca Regional, dado que este conjunto es exclusivo de una región determinada, en este caso la costa central peruana.

Dentro de este grupo, que llamaríamos Inca Regional, se encuentra una serie de vasijas cara-golletes, elaboradas tanto en ambiente reductor como oxidante. El motivo escultórico, presente en las vasijas cara-gollete se aplica también a varios tipos de botellas y jarras, en especial estas últimas, sea con el cuerpo carenado, base plana y

(23) Incluso aparecen con cierta frecuencia en los contextos de este periodo varias vasijas totalmente atípicas, en especial aquellas escultóricas. Algunas de estas raras piezas son reproducidas por Schmidt (1929). También ver: Cornejo, 2003: figs. 2b y 3b; Makowski, 2003: fig. 10c 
cuello evertido; o con el cuerpo enteramente globular. Algunas de estas vasijas incluso reproducen los brazos del personaje, incisos en el cuerpo de la vasija y/o pintados. Estas vasijas pueden presentarse de color negro (ambiente reductor) o policromadas, en acabado mate o pulido (Uhle, 1903: fig. 79 y lam.13, figs. 3, 4; Bazán, 1990: lam. 35, fig. a; Cornejo, 2000: foto 3; 2003: figs. 1a, 1b, 2a, 2c, 3a, 3c, 4d, 5a, 5d).

También se vuelven populares, un grupo de pequeñas botellas con el cuerpo en forma de cucurbitáceas, con el cuello alto, ligeramente abierto; aunque el número, tipo y posición de las asas suele ser variada. El tratamiento más usual de estas botellas es en ambiente reductor, pero existen especimenes en tratamiento oxidante, engobadas en ocre o pulidas, y con líneas cremas remarcando los detalles. En algunos casos en la unión del cuello con el cuerpo suele añadirse un reborde circular con incisiones zigzagueantes (Uhle, 1903: figs. 69, 70, 71, 86 y lam. 13, fig. 13; Engel, 1984: 4435; Franco, 1998: lam. 47 fig. 14).

Otra vasija recurrente en los contextos de esta fase es la que consiste en una botella que representa a un personaje masculino, con las facciones del rostro bien elaboradas y el tocado que se convierte en el borde mismo de la botella. El cuerpo de la vasija sirve para representar a su vez el cuerpo del personaje, donde se detallan sus extremidades inferiores y los pies. Las extremidades superiores suelen ser representadas con mayor realismo y detalle (Uhle, 1903: lam.13, fig. 2).

Una botella particularmente vistosa y bastante recurrente es la de doble cuerpo, elaborada en ambiente reductor y de acabado pulido; ambas botellas se unen en el cuerpo por un asa puente a la altura de los cuellos (Fig. 18). El común de estas vasijas es el tipo silbador, para lo cual se ubica siempre un figurín escultórico en el tope del cuello de una de las botellas, colocándose precisamente debajo de este figurín el silbato (Uhle, 1903: lam. 13, fig. 8, lam. 18 fig. 12; Engel, 1984: 4480; Isla, 1995: figs. 7c, d, e; Makowski, 2003: fig. 10a).

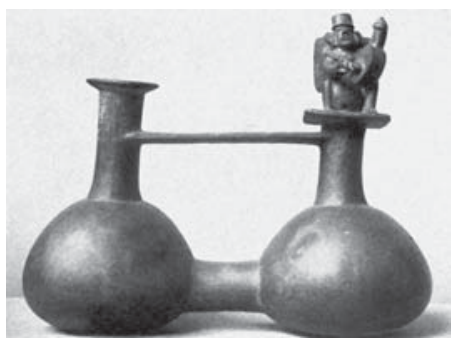

Fig. 18 - Botella de doble cuerpo silbadora del estilo Inca Regional (Schmidt, 1929).

Otra vasija perteneciente a este grupo, es un cuenco de contorno fuertemente carenado y base ligeramente convexa o plana. El labio presenta por lo regular un pequeño reborde. Estos cuencos tienen como características principales su manufactura en color negro, por ambiente reductor y su decoración estampada de figuras muy pequeñas de aves, cruces romboides escalonadas, círculos y otros diseños estilizados, distribuidos entre paneles trapezoidales o triangulares definidos por líneas incisas. En varios casos se encuentra pintura post-cocción de color blanco y rojo al interior de estos diseños estampados (Strong \& Corbett, 1943: fig 10e, 11e; Silva, 1992: figs. 150, 152). 
Algunas miniaturas en forma de pequeños cuencos, también aplican este tipo de decoración estampada, con similares motivos iconográficos y apliques de pintura postcocción (Ravines \& Stothert, 1976: Sp. An26/76f).

Entre las miniaturas existe una muy usada, la cual se compone de un pequeño plato de base convexa al que se le ha añadido a la altura del borde cuatro apéndices que representan las alas, cola y cabeza de un ave. La cabeza del ave es tratada escultóricamente, mientras que en las alas y cola se resaltan sus elementos con incisiones. Algunas veces, las partes internas de las incisiones y detalles de la cabeza del ave, son decoradas con pintura post-cocción en colores invariablemente blanco y rojo (Uhle, 1903: lam. 18 fig. 10; Engel, 1984: plate 4, p. 4347; Isla, 1995: fig. 3d). Las miniaturas son frecuentes en los contextos de esta fase, existiendo gran variedad de ellas, especialmente de pequeñas ollas, platos y cuencos. Por lo general, el acabado de este tipo de vasijas en miniatura suele ser vistoso, con pulimento superficial, engobes, incisiones y en pocos casos aplicaciones de pintura. En algunos casos raros, se aplican incluso detalles escultóricos en ellas (Isla, 1995: figs. 3c, 5a; Franco, 1998: lam. 47, fig.13).

Las formas escultóricas suelen ser bastante variadas, tanto las polícromas como las de color negro, aunque en algunos casos hay recurrencia en el tipo de representación. Son algo usuales la representación de un pescador o un personaje montado sobre un caballito de totora (Canziani, 1983) o la de un cargador de vasijas de cerámica (Disselhoff, 1961:224) (Fig. 19b). En otros casos estas formas escultóricas son bastante complejas, incorporando elementos plásticos de varias tradiciones cerámicas; sin embargo, son escasas en comparación con los otros tipos cerámicos que conforman el corpus del Inca Regional.

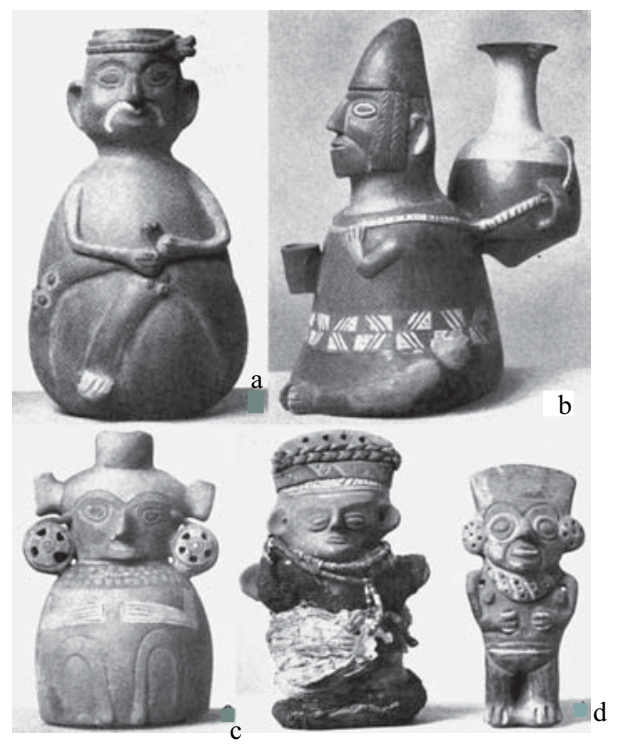

Fig. 19 - Cerámica del estilo Inca Regional (a, b, c) y del estilo Ychsma Tardío B (d) (Schmidt, 1929). 
Un tipo de botella escultórica que parece ser bastante usada representa a un personaje de facciones toscas, sujetándose una de las extremidades (Fig. 19a). El acabado es casi siempre en negro por la cocción reductora empleada y de superficie pulida (Schmidt, 1929; Engel, 1984: plate 20, 3244).

En general, las botellas del Inca Regional son muy variadas, en especial aquellas de color negro trabajadas en ambiente reductor y que presentan siempre un acabado muy pulido y brillante. El elemento morfológico común en ellas está constituido por el tipo de cuello, de tipo angosto con el labio evertido; un asa pequeña cintada es colocada en la unión de la base del cuello con el tercio superior de la vasija. Los cuerpos presentan las mayores variantes, utilizando temáticas diversas pero principalmente de elementos fitomorfos como frutos y tubérculos, o elementos zoomorfos como caracoles (Uhle, 1903: lam. 13, figs. 14, 15). Las variantes en este grupo cerámico están mayormente constituidas por botellas que combinan varios elementos temáticos escultóricos, siendo estas de construcción compleja y elaborada (Uhle, 1903: lam. 18, fig.11). En algunos casos las botellas que tienen el mismo acabado en ambiente reductor y pulido, utilizan apliques escultóricos en la unión del cuello con el cuerpo y tanto el asa como el cuello recuerdan más las formas del estilo Ychsma (Guerrero, 1998: 101 [arriba]).

Una forma escultórica, seguramente de uso ritual, es la que representa a un personaje femenino, de cabeza o tocado en forma trapezoidal. Este personaje suele ser representado sentado y es común el tratamiento en color negro pulido, con detalles incisos y modelados; pequeñas aplicaciones de pintura suelen resaltar algunos de los detalles representados (Fig. 19c). Adiciones como orejeras escultóricas, algunas finamente trabajadas, son también frecuentes en estas formas antropomorfas (Schmidt, 1929; Hyslop \& Mujica, 1992: fig. 21).

Otro tipo de pieza escultórica, muy rara, parece representar al mismo personaje femenino, pero de pie y con los brazos abiertos a los lados; el tocado es también algo trapezoidal. Este tipo de representaciones guarda mucha correspondencia con piezas similares del valle de Chancay y con las figurinas femeninas del estilo Ychsma; sin embargo, en este caso su acabado es en color negro producto del ambiente reductor, la superficie pulida y con adiciones decorativas como líneas incisas zigzagueantes y puntos estampados entre ellas. Los ojos son de forma romboidal alargada (Bazan, 1990: lam. 34). De igual manera, existe un tipo de variantes en estas piezas escultóricas bastante elaborado, que utiliza las incisiones y los bajo relieves de manera profusa para resaltar varios detalles, principalmente, de los ornamentos que acompañan al personaje, como un tipo especial de cara-gollete (Uhle, 1903: fig. 81).

Las formas cerámicas Inca del tipo "paqcha” encuentran gran difusión y diversidad en los motivos representados, manteniendo siempre estas características escultóricas, así como muestran gran variedad en los acabados (Canziani, 1983: fig. saltamontes y fig. caracol).

Los acabados en el Inca Regional son bastante finos, como las vasijas de superficie pulida terminadas en cocción reductora, algunas de las cuales presentan un acabado en color negro brillante muy particular, denominado como "plombatinado" o plombaginado. Muchas de las formas incas aribaloides reproducidas en pequeñas jarras 
o cántaros de color negro pulido con la reproducción de un rostro en el gollete (Bonavía, 1959: lam. XVI), son frecuentemente acabadas con la técnica del plombatinado, aunque existen variantes con decoración polícroma elaboradas en ambiente oxidante (Uhle, 1903: lam. 18 fig. 2). Un tipo frecuente de forma aribaloide es elaborado en ambiente reductor y presenta en el cuello la reproducción de un rostro, de facciones algo similares a las que se reproducen en las jarras aribaloides, pero que añade además una decoración incisa en el cuerpo de la vasija con detalles de los brazos y manos del personaje (Ravines \& Stothert, 1976: Sp. An06/ 76; Silva, 1992: fig. 81).

También se usan repetidamente engobes de color naranja, con acabado pulido y engobes de color rojo violáceo con acabado mate; en este ultimo tipo de engobe suele asociarse casi siempre un tipo de pasta que incorpora gran cantidad de elementos líticos molidos como el granito.

Para el Inca Regional, existen variados tipos de cuencos y platones, por lo general acabados en superficie pulida sobre un engobe de color naranja o marrón claro. A veces es notoria una capa de pintura marrón que sustituye o se superpone al engobe y que se aplica en toda la superficie externa de estas vasijas pero de forma irregular (Bonavia 1959: lam. XV).

\section{7. La Fase Ychsma Tardío B}

En la fase Ychsma Tardío B se consolidan muchos de los cambios de la fase anterior, pero es evidente que los cambios son de mayor trascendencia y que exceden a los elementos cerámicos. En lo que respecta a las formas propiamente del estilo Ychsma, hay varias que son únicas de esta fase y aunque no necesariamente adoptan modelos iconográficos cuzqueños, se asocian contextualmente y cronológicamente con los tipos cerámicos Inca; sin embargo, por técnica, morfología y decoración pertenecen a la tradición cerámica local, por lo cual se les ha segregado como pertenecientes a la fase Ychsma Tardío B (Fig. 20).

Entre las vasijas propias de esta fase, están un tipo de tazones o platos hondos, en los cuales la característica principal es la de presentar un par de sapos escultóricos, elaborados en molde y que funcionan a manera de pequeñas asas (Fig. 20 d). Estos sapos siempre se ubican en par y en el borde de las vasijas, uniéndose con la parte superior del cuerpo. La base es convexa y el contorno presenta siempre un carenado o aquillado. La decoración pictórica consiste en el cubrimiento en crema de la parte media y superior de la vasija y, a menudo, la aplicación adicional de líneas negras que describen motivos geométricos en los bordes internos y en el tercio superior externo (Bueno, 1983; Bazán, 1990: lam. 20; Isla, 1995: fig. 3a; Eeckhout, 1995: fig. 28a; 1999: fig. 16g, 16h; Franco, 1998: lam. 43, figs. 3, 4, 5 y lam. 44, fig. 11; Córdova, 2000: foto 191; Guzmán, 2002: fig. a). La aplicación de estos figurines escultóricos en muy pocos casos se incorpora a otras formas cerámicas como cántaros o cuencos de cuerpo globular (Bazán, 1990: lam. 43; Isla, 1995: fig. 3b).

Otro tipo de vasijas típicas de esta fase, son las ollas con decoración en relieve de serpientes ondulantes dispuestas en posición horizontal, que se ubican tanto en el cuerpo como en los cuellos de estas vasijas (Fig. 20a, b, f). Existen varios tipos 


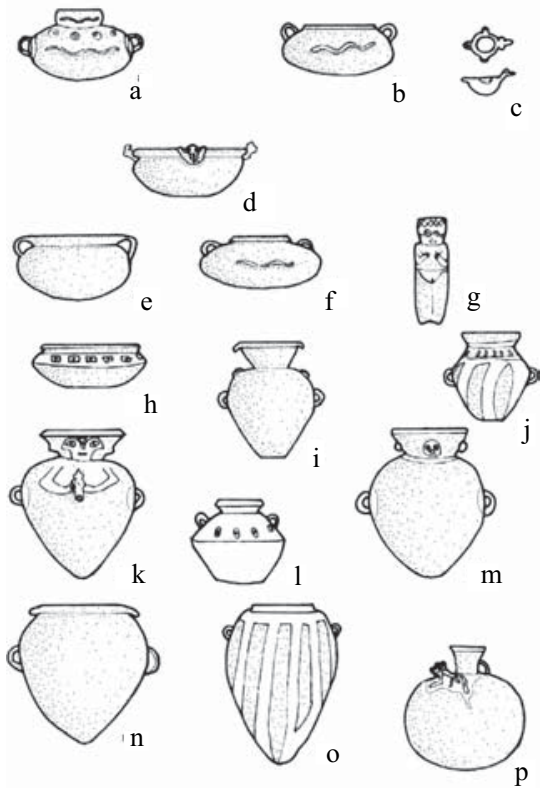

Fig. 20 - Formas cerámicas de la fase Ychsma Tardío B.

principales de ollas que incorporan este tipo de decoración; la más común consiste en una de cuerpo globular, asas cintadas en el cuerpo y cuello convexo (Fig. 20a). La otra es también una olla, pero de cuerpo más oblongo, sin cuello; a veces un reborde biselado reemplaza al cuello y da más resalte al borde (Isla, 1995: fig. 4b). Las asas cintadas son alargadas y elevadas (Fig. 20f) o también aquéllas que prácticamente no presentan cuello (Fig. 20b). La decoración pictórica en estos dos tipos de vasijas con serpientes es siempre en color crema sobre un fondo rojizo a veces violáceo, producto del engobe que se aplica sobre este tipo de vasijas. Los elementos en crema se aplican a manera de pequeños círculos sobre el lomo de las serpientes, líneas paralelas sobre las asas y franjas alrededor de las asas y en el borde de las vasijas. En algunos casos varias protuberancias circulares acompañan a los diseños en relieve de las serpientes. Un caso poco frecuente es la aplicación del motivo serpentiforme en las ollas de cuello abierto y de asas laterales en la unión del labio con el cuerpo; o en ollas donde se le adiciona también la decoración pictórica en bandas de color crema (Uhle, 1903: fig. 85; Engel, 1984: 3226; Bazán, 1990: lams. 15, 32a, 39a-b; Silva, 1992: fig. 71, 78, 79; Eeckhout, 1995: fig. 20; Franco, 1998: lam. 46, fig.10) (24). Algunas raras variantes incluso incorporan adicionalmente una decoración estampada en el cuerpo de la vasija (Isla, 1995: fig. 4c). Muchas de estas vasijas son halladas con claras huellas de uso, generalmente impregnadas de hollín, lo que denota su utilidad doméstica (Fig. 21a).

(24) Una variante a estos tipos principales es presentada también por Engel, 1984: 4537; Córdova, 2000: foto 193. 


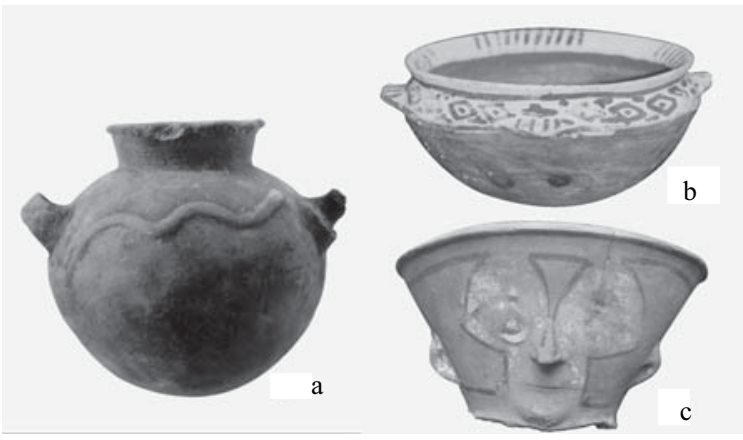

Fig. 21 - Cerámica perteneciente a la fase Ychsma Tardío B. Armatambo.

Una variante importante en las vasijas que incorporan la decoración serpentiforme es la de aquéllas que le adicionan la decoración estampada de círculos; estos suelen ser pequeños y se ubican en el lomo de la serpiente. Es recurrente la asociación entre la decoración serpentiforme con el estampado de pequeños círculos, en vasijas que utilizan la pasta arcillosa de color marrón y temperantes de cuarzo lechoso (pasta de tipo C o Lomas), aunque existen también las que utilizan otros tipos de pasta; el acabado es mayormente rústico exhibiendo únicamente la superficie natural, con poco trabajo de alisado (Bazán, 1990: lam. 45a ; Silva, 1992: fig. 135; Franco, 1998: lam. 41, fig. 3) (25).

Las ollas sin cuello en esta fase alcanzan gran popularidad, existiendo diversas variantes entre ellas; aunque manteniendo una conformación común, como el cuerpo oblongo de base ligeramente convexa, asas laterales cintadas, en posición vertical, algunas veces alargadas y sobreelevadas con respecto a la altura del borde (Fig. 20b); o también manteniendo las mismas características del cuerpo, pero con las asas en posición horizontal. Por lo general, su acabado es en natural o también con engobes rojo oscuro o rojo violáceo, con aplicaciones de pintura crema (Engel, 1984: plate 5, p. 4557 y plate 7, p. 4281; Negro \& Fuentes, 1989: Fb-6; Silva, 1992: fig. 82; Eeckhout, 1995: fig. 21). Existe también un tipo de olla sin cuello, que parece reproducir formas anteriores, pero que en esta fase presenta aplicaciones de engobe rojizo y pintura crema alrededor del borde o en casos raros, aplicaciones escultóricas (Isla, 1995: fíg. 4a).

Una botella también es recurrente en esta fase, la cual está constituida por el cuerpo globular, base plana, asas cintadas laterales en posición vertical y cuello angosto del tipo "tulipa", a veces algo más alargado que el que se presentaba en vasijas similares de fases anteriores. La decoración de estas vasijas es pictórica, compuesta por líneas negras en diseños geométricos, a manera usual de líneas zigzagueantes paralelas, sobre un fondo crema. Estos diseños se ubican torno al cuello, sobre el tercio superior del cuerpo de la botella (Engel, 1984: plate 10 p. 4066).

Las botellas en general son bastante variadas existiendo diversos tipos. Una de ellas está compuesta por un cuerpo globular, con asas laterales pequeñas y alzadas sobre

(25) Material similar también se ha reportado procedente del sitio de Chocas en el valle del Chillón. Ver: Pérez \& Arce, 1989: lam. XII 
el cuerpo de la vasija; el cuello es angosto y su terminación bastante expandida. En algunos casos, este tipo de botellas presenta un trabajo escultórico alrededor del cuello en la unión con el cuerpo, simulando una pequeña pirámide escalonada (Guerrero, 1998: 99). En estas vasijas es frecuente la aplicación de pintura crema sobre este detalle escultórico y el borde, con la superficie del cuerpo alisado en color natural o naranja claro.

Las botellas del tipo cantimplora, usuales en las fases Ychsma precedentes, son frecuentemente trabajadas ahora en ambiente reductor y con bastante pulimento superficial. El borde suele ser recto y divergente (Silva, 1992: fig. 88; Isla, 1995: fig. 5c; Makowski, 2003: fig. 9).

Entre los elementos decorativos de esta fase está la de un figurín antropomorfo elaborado en molde que suele añadirse al cuello de algunos cántaros, especialmente de aquellos que tienen forma y dimensiones similares a las usadas por los tipos caragollete (Fig. 20m). La forma de este figurín moldeado es bastante repetitiva, pues suele mantener las mismas facciones en todos los casos, que asemejan bastante las facciones de un infante. Este tipo cerámico proviene de o se relaciona directamente con la fase anterior donde las facciones del personaje son más toscas y con las orejas dispuestas cerca del rostro (Fig. 14a). El rostro en la fase Tardío B es siempre de forma redondeada y en algunos casos se le añade un par de orejas modeladas a cada lado del cuello de la vasija (Strong \& Corbett, 1943: fig. 10e; Bazán, 1990: lam. 22; Franco, 1998: fig. 45 nº 3).

Muchas formas cerámicas de las fases anteriores entran en un nuevo desarrollo durante esta fase, en especial presentando un acabado en ambiente reductor bien controlado, lo que les proporciona un color negro muy intenso, además del efecto del pulido superficial. En este grupo se encuentran una serie de vasijas de tamaño mediano, con un ancho cuerpo globular, cuello angosto y borde expandido. El asa se ubica entre el cuello y el tercio superior del cuerpo. A estas vasijas, se les suele añadir un aplique escultórico representando por lo general a un felino en una postura echada (Fig. 20p) (Silva, 1992: fig. 90). En otras formas cerámicas, pero siempre tratadas en ambiente reductor, se aplica la representación escultórica de un mono con una de sus extremidades sobre la cara (Eeckhout, 1995: fig. 29). La utilización de elementos escultóricos, como felinos o monos, en diversas formas cerámicas, muestra mayor libertad y frecuencia, sumado a un mejor tratamiento de los detalles escultóricos de estas representaciones (Isla, 1995: fig. 7a).

Entre estas vasijas de cocción reductora existe una de contorno carenado y labios fuertemente biselados, con aplicaciones en relieve de protuberancias ovales y alargadas (Fig. 201). Estas aplicaciones son bastante peculiares resaltándose el motivo con incisiones paralelas en sentido longitudinal (Engel, 1984: plate 8, p. 3973; Silva, 1992: fig. 149).

Los cambios morfológicos en esta fase son muy variados, aunque se encuentran enmarcados dentro de un comportamiento similar que afecta a la mayoría de tipos cerámicos. Los patrones de cambio están generalmente establecidos por el uso más frecuente de bases planas, asas cintadas, labios con bordes o rebordes fuertemente biselados (Fig. 20f, k, 1) (Engel, 1984: 4273; Silva, 1992: fig. 80) o labios con un grueso reborde pendiente (Fig. 20i) (Silva, 1992: fig. 115). También es recurrente la utilización 
de cuellos expandidos de forma acampanulada (Negro \& Fuentes, 1989: Fc-3; Isla, 1995: fig. 5c). En diversas vasijas la decoración es, frecuentemente, en base a bandas paralelas de color blanco o crema (Figs. $20 \mathrm{j}$, o), que a menudo presentan además un círculo pintado alrededor de la base del asa, también del mismo color, aplicado en ambos casos sobre una base engobada de color rojo violáceo (Silva, 1992: figs. 82, 84).

Las vasijas del tipo cara-gollete pertenecientes a esta fase son casi siempre acabadas con cuello más expandido o evertido y el labio bastante biselado (Fig. 21c); incluso los diseños del rostro del personaje son bien delineados en estilizaciones bastante recurrentes, con trazos más rectilíneos y de líneas más delgadas (Fig. 20k). Los detalles escultóricos en este tipo de vasijas son a veces pequeños, como la nariz y los ojos que disminuyen de tamaño con respecto a las fases precedentes (Bueno, 1983: 26, fig. a; Franco, 1998: lam. 45, figs. 15, 17; Guzmán, 2002: figs. e, f_los diseños sin embargo aparecen en la publicación invertidos-). Con todo, las variantes durante esta fase en el tipo cara-gollete, son numerosas y de diversa índole, mezclándose muchos elementos iconográficos y morfológicos, restringidos anteriormente a otras vasijas o que surgen exclusivamente en esta fase (Uhle 1903: lam.13 figs. 5, 6).

Una variante de las vasijas cara-gollete bastante novedosa en esta fase, está dada por un grupo que utiliza la técnica de cocción reductora, con acabado de la superficie pulida (Strong \& Corbett, 1943: fig. 11g). Los detalles escultóricos del personaje representado son similares al de los cara-golletes de cocción oxidante pero en menor tamaño; existen además varios casos donde los ojos son de forma alada (Franco, 1998: lam. 42, fig. 1).

Otras variantes en las vasijas cara-gollete lo constituyen un grupo de cántaros que reproducen el rostro modelado de un personaje, pero en posición sentada, con las extremidades inferiores resaltadas por detalles escultóricos o pictóricos. Los pies igualmente son representados en forma escultórica en varios casos, que se adaptan a la base plana. Los acabados de estas vasijas son variados, predominando los acabados mate, aunque existen especimenes pulidos. El cuello es usualmente recto, con el labio redondeado y las facciones del rostro del personaje tratadas escultóricamente con mayor detalle. Los ojos muchas veces son romboidales o alados (Hyslop \& Mujica, 1992: fig. 23 [B/1132 y B/1128]; Cornejo, 2003: figs. 2b, 2d, 3b, 3d, 4b, 5c).

Esta misma representación, aunque prescindiendo de los detalles de las extremidades inferiores y los pies, es hallada en cántaros de cuello recto, cuerpo globular ovoide y de base convexa o plana. La posición de los brazos y las manos suele ser variada (Hyslop \& Mujica, 1992: fig. 23 [B/1125]; Isla, 1995: figs. 6a, b).

En algunas botellas o jarras pequeñas, suele también reproducirse el rostro de un personaje con bastante afinidad a las vasijas cara-gollete de mayor tamaño. Los pies se representan en la base de la vasija con dos pequeñas aplicaciones salientes. En algunos casos el rostro es de características zoomorfas, imitando las facciones de un ave. El cuerpo de la botella es usado para representar otros elementos del personaje, como las manos. La decoración de este tipo de botellas es variable: puede ser solamente pictórica en color negro sobre una base crema, negro pulido por cocción reductora o utilizar líneas incisas (Isla, 1995: fig. 6c). 
Los cuencos aquillados alcanzan gran difusión en esta fase, mejorando incluso su conformación plástica. En varios casos resalta la aplicación de un engobe marrón en la parte externa inferior e interior de la vasija, donde anteriormente se presentaba únicamente la arcilla natural (Fig. 21b). Una variante de este tipo de vasijas es una que incorpora una aplicación escultórica de la cabeza de un ave estilizada, de perfil alargado, que se ubica alrededor del cuello, en el tercio superior de la vasija; las alas y la cola son también aplicadas a la misma altura con respecto al borde de la vasija. Dichas aplicaciones servían también como asas (Franco, 1998: lam. 45, fig. 2; Eeckhout, 1999: fig. 16f).

Las ollas y cántaros usan mayormente la decoración de gruesas bandas paralelas ubicadas verticalmente en el cuerpo de la vasija (Fig. 22). Estas gruesas líneas a manera de bandas se pintan siempre en color crema sobre el fondo rojo natural (Ravines \& Stothert, 1976: Sp. An05/76; Engel, 1984: 4459, 4470; Ravines, 1994: figs. 543, 544), con un tratamiento mucho más delineado y rectilíneo que los toscos brochazos de las fases anteriores (Bazán, 1990: fig. 16a). Las asas en las ollas, aplicadas en la unión del cuello con el cuerpo, suelen ser más anchas y a veces un pequeño reborde superior que excede el nivel del labio. El cuello de estas ollas también suele ser más evertido (Franco, 1998: lam. 46, fig. 1; Córdova, 2000: foto 196).

Los componentes y tipos de arcillas empleadas en la producción de la cerámica, son más seleccionados y es frecuente el uso de temperantes líticos, como el granito molido. La presencia de este tipo de elementos líticos será más evidente en las vasijas engobadas de rojo violáceo, denotando talleres especializados en las zonas donde este material existe. El uso de estos temperantes líticos es constante en las tinajas y otras grandes vasijas; es claro que el objeto de añadir este tipo de temperantes e inclusiones en la pasta, se relaciona con la dureza y mayor solidez que estas vasijas adquirían luego de la cocción, predominando por ello los tipos cerámicos que utilizan la pasta del tipo B o "quebrada".

Entre las vasijas más características de esta fase, están las tinajas del tipo "pepino", denominadas así por la forma y decoración que exhiben (Fig. 20o). Estas tinajas presentan siempre un cuerpo ovoide alargado, con un par de asas laterales ubicadas en el tercio superior. La decoración es constante y similar en todas ellas,

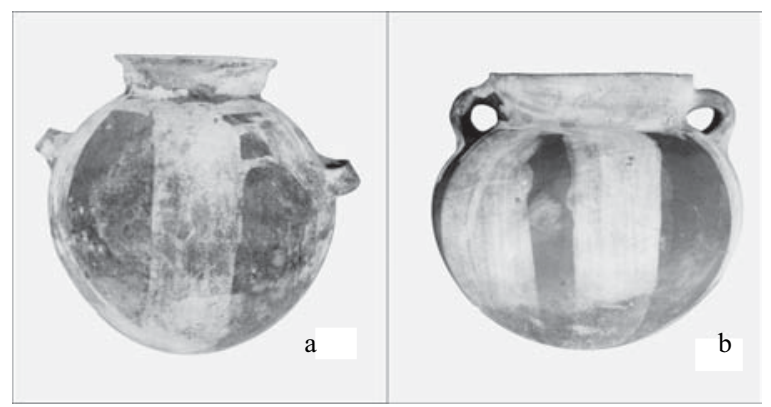

Fig. 22 - Ollas típicas de la fase Tardío B. La Rinconada. 
consistiendo en una serie de franjas paralelas de color crema que recorren verticalmente el cuerpo de la tinaja. El cuello es pequeño, con un grueso reborde externo en el labio (Uhle, 1903: fig. 66; Hyslop \& Mujica, 1992: fig. 19).

Otro tipo de tinajas provenientes de la fase anterior, que utilizan un grueso reborde en el labio de forma lenticular (Fig. 20n), algunas veces con bastante saliente, aparece ahora con mucha más frecuencia (Silva, 1992: fig. 108).

Uno de los cambios importantes en esta fase está en el uso de moldes, especialmente en la elaboración de figurinas femeninas, las cuales se volverán muy populares y variadas, aunque manteniendo los mismos cánones de concepto (Fig. 20g). Es común también el adicionarle a estas figurinas una capa de pintura crema sobre toda la superficie o en algunos de los detalles escultóricos (Fig. 19d) (Uhle, 1903: fig. 87; Ravines \& Stothert, 1976: Sp. An26/76g; Engel, 1984: plate 21, p. 4587, 3884, 4582; Vallejo, 1988: fig. 12; Eeckhout, 1995: fig. 19; Guerrero, 1998: 104 arriba).

Muchos de los motivos y diseños del Ychsma Tardío B reproducen los elementos iconográficos de las fases anteriores, en especial el de los peces, siempre delineados en color negro sobre una base crema o blanca (Engel, 1984: 4490; Franco, 1998: lam. 45 figs. 6, 10; Guzmán, 2002:fig. g); o también se incorporan motivos tomados aparentemente de los textiles por su trazo geométrico, como escalonados y aves estilizadas (Engel, 1984: plate 8, p. 3975, 4489 y plate 10, p. 3260), aunque también existen especímenes donde el diseño es bastante libre (Isla, 1995: fig. 5b). En varios casos los motivos se restringen a círculos en blanco o crema, delimitados por líneas en color negro que se aplican generalmente en el cuerpo de las vasijas globulares (Strong \& Corbett, 1943: fig. 12f). En las vasijas mejor trabajadas, todos estos diseños representados tienen una buena composición y el trazo es mejor delineado; y es frecuente que los bordes internos o las asas presenten decoración pictórica de delgadas líneas paralelas, círculos y escalonados (Strong \& Corbett, 1943: fig. 9e, f; Franco, 1998: lam. 46 figs. 2, 4).

Se continúa aplicando la decoración estampada de círculos como en las fases anteriores, en especial en ollas de manufactura tosca (Franco, 1998: lam. 46, fig. 13).

\section{DISCUSIÓN}

Si bien el trabajo de clasificación y seriación de la cerámica Ychsma aparenta ser estructurado a partir de criterios puramente estilísticos, lo cierto es que éste obedece estrictamente a criterios arqueológicos contextuales. De hecho, se ha tomado como principal punto de referencia los estudios de campo efectuados en los sitios de Armatambo (Díaz, 1998; 2000; 2004a; 2004b; Díaz \& Vallejo 2002; 2003a; 2003b; 2004; Ruales et al., 1983; Vallejo, 1988; 1998) y La Rinconada (Díaz, 2002); como a su vez, la comparación de estos datos con los hallazgos y estudios desarrollados por diversos investigadores tanto en Armatambo (Bazán, 1990; Bragayrag, 1982; Pérez, 1997), y en otros sitios del espacio geográfico involucrado, como los de Pachacamac (Bueno, 1982; 1983; Eeckhout, 1995; 1999; Franco, 1993; 1998; Franco \& Paredes, 2000; Menzel, 1968; Paredes \& Ramos, 1994; Strong \& Corbett, 1943; Uhle, 1903); Huallamarca (Casas \& Dolorier, 2004); Puerto Viejo (Bonavía, 1959); Huaca San Borja (Rea, 2001); El Sauce (Córdova, 2000); La Salina (Machacuay \& Aramburú, 1998); Isla 
San Lorenzo (Isla, 1995); Huachipa- Jicamarca (Silva, 1992); Pueblo Viejo (Makowski, 2003); entre otros. Incluso se ha efectuado algunas correlaciones con material de valles o áreas geográficas aledañas como los de Ancón (Ravines, 1981; Ravines \& Stothert, 1976); Chocas (Pérez \& Arce, 1989) y del valle medio de Chilca (Engel, 1984; González, 2001).

Dado que Armatambo, corresponde a un sitio de especial relevancia en el contexto social y político del grupo cultural Ychsma, es claro que los hallazgos arqueológicos en términos de correlación estratigráfica y estilo cerámico, sean también en gran parte correspondientes al total del espacio Ychsma.

De por sí, este estudio intenta esbozar un primer cuadro general de la cerámica del estilo Ychsma en sus diferentes fases y periodos cronológicos. Es claro que los tipos cerámicos involucrados en este proceso son mayores de los aquí representados, pues varios de ellos corresponden a contextos arqueológicos que están actualmente en trabajo de clasificación y estudio. Es importante señalar que varios de estos contextos son fundamentales para llegar a un estudio completo de la cerámica Ychsma, como por ejemplo los contextos de enterramiento ritual de cerámica hallados en La Rinconada, correspondientes con la fase Ychsma Medio A (Díaz, 2002), basurales arqueológicos pertenecientes a la fase Tardío B (Díaz, 1998) y el reciente descubrimiento en Armatambo de un denso cementerio correspondiente con las fases Medio B y Tardío A (Díaz, 2004b) de la secuencia Ychsma aquí propuestas.

Siendo la cerámica uno de los principales indicadores arqueológicos, tanto a nivel de secuencia cronológica como de características culturales y estilísticas, resulta evidente que la sociedad Ychsma, antes de la dominación incaica, mantuvo en gran parte su desarrollo en el mismo espacio geográfico comprendido principalmente entre los valles bajos del Rímac y del Lurín, con áreas de control en las lomas inmediatas y en la quebrada de Chilca. Su extensión hacia las vertientes occidentales próximas en general no alcanzó áreas geográficas más allá de la chaupiyunga, por lo que se puede afirmar que se trató principalmente de una sociedad y una cultura propia del litoral y las quebradas inmediatas.

En el desarrollo de la secuencia cerámica Ychsma, es notoria por un lado, la presencia de material proveniente de la zona de Huaura para las fases tempranas y de Chancay para las fases medias. Algunas de estas piezas son incluso pertenecientes a estos valles y fueron en algún momento trasladadas a los valles del Rímac y del Lurín; otras más bien son el resultado de una fuerte y constante influencia proveniente de estos valles hacia el área Ychsma. Diversas hipótesis se pueden esbozar en torno a este hecho, desde los contactos puramente comerciales y de intercambio, como la existencia del Santuario de Pachacamac que debió generar movimientos de población a efectos de peregrinaje.

Por el contrario, es también notoria la ausencia de material cerámico proveniente del valle de Chincha o de formas que hayan sido elaboradas con su influencia. Siendo la cerámica Chincha particularmente vistosa y de buen acabado, es casi incomprensible esta ausencia en el corpus cerámico Ychsma. Basta comparar las formas presentadas por Menzel (1976) para el estilo Chincha, con las formas y tipos cerámicos Ychsma, para ver la total incomunicación entre estas dos tradiciones cerámicas. 
La incorporación de la sociedad Ychsma o del llamado Señorío de Ychsma (Rostworowski, 1972; 1978) al organigrama político incaico, de hecho tuvo fuertes repercusiones en las manufacturas cerámicas, haciendo que éstas encuentren nuevas variantes estilísticas y que sus mecanismos de distribución se dinamicen ostensiblemente. Es claro que en este periodo, coincidente con la parte final de la fase Ychsma Tardío A y especialmente con toda la fase Ychsma Tardío B, los especímenes cerámicos Ychsma alcanzan de manera recurrente otras áreas geográficas como el bajo Chillón, Ancón e incluso Mala ( la información histórica, la cual señala la existencia de una unidad política incaica correspondiente a los valles bajos del Chillón, Rímac y Lurín, expresada en tres importantes Hunu: Carahuayllo, Maranga y Surco (Cobo, 1882[1639]: 42), de la cual ya se ha venido sistematizando su estudio a partir de la llamada Provincia incaica de Pachacamac (Cornejo, 2000; Díaz \& Vallejo, 2003b; 2004).

La llegada de los españoles en 1533 a Pachacamac marca un punto de ruptura en la continuidad y supervivencia del estilo Ychsma. Aunque es seguro que durante los primeros años de la Conquista y la Colonia la cerámica debió continuar produciéndose, es evidente que los niveles y características formales de la misma se fueron perdiendo a la par de la extinción de la población indígena local y del abandono progresivo de sus patrones culturales propios. No es raro por ello que prácticamente no se conozcan especimenes cerámicos que mezclen los nuevos elementos hispánicos con los provenientes del antiguo estilo Ychsma.

\section{CONCLUSIONES}

La definición geográfica, estilística y secuencial del corpus cerámico Ychsma, constituye una pauta importante en la consolidación del concepto de una sociedad y una estructura política del mismo nombre, que funcionó durante el Intermedio Tardío en la costa central peruana, básicamente en los valles bajos del Rímac y del Lurín.

Desde el punto de vista geográfico, estos dos valles representan el área nuclear de la sociedad o cultura Ychsma, con extensiones e influencias hacia los valles aledaños. Si cuantificamos el área productiva del territorio Ychsma, incluyendo por supuesto las áreas de cultivo, las lomas y el litoral pesquero, entre otras, veremos que los rangos de obtención de alimentos son muy importantes, capaces por sí solos, para el mantenimiento de un nivel poblacional alto y económicamente autosustentable, capaz de servir de base a la estructura económica de cualquier unidad política y social desarrollada. Aunque es necesario profundizar en las investigaciones del aspecto económico, político y social de la cultura Ychsma, la definición de los tipos cerámicos Ychsma establece la posibilidad de situar los sitios y contextos arqueológicos existentes en un marco espacial y temporal, elemento necesario para la comprensión del desarrollo evolutivo de esta sociedad.

Bajo el criterio estilístico era imprescindible la definición arqueológica del estilo Ychsma en vista de la existencia de denominaciones anteriores, las cuales se restringían solo a determinados tipos cerámicos del propio estilo Ychsma, dando una lectura parcial y quizás equivocada de la situación espacial de esta sociedad. Es claro, por ejemplo, que las denominaciones anteriores de Huancho o Puerto Viejo son en esencia propuestas de trabajo que se esbozaron en un primer momento de la investigación arqueológica, pero 
que fueron asumidas rápidamente por otros investigadores, al punto que en algunos casos aparecen ambas denominaciones de Huancho o Puerto Viejo, como estilos diferentes y aun como correspondientes a áreas geográficas distintas. En realidad, ambos grupos, definidos en base a ciertas características decorativas principalmente, son parte integrante del corpus cerámico Ychsma y más bien representan diferenciaciones temporales propias de la evolución del estilo a través del tiempo.

Con respecto a la secuencia, se ha visto que el incremento de las investigaciones arqueológicas en el territorio Ychsma y especialmente en una lectura adecuada de las relaciones estratigráficas y de los contextos asociados, han permitido realizar una seriación del material cerámico en grupos estilístico-cronológicos que obedecen también a importantes características de comportamiento de la sociedad Ychsma. Así, por un lado, las variaciones más importantes, registradas a partir de cambios en los diversos órdenes de actuación y dinamismo social de la cultura Ychsma, han sido agrupados en tres grandes épocas denominadas Temprano, Medio y Tardío; cada una de ellas definiendo determinados tipos de comportamiento y características culturales. Por otro lado, la posibilidad de aislar arqueológicamente grupos cerámicos específicos al interior de estas épocas, ha sido expresada a través de fases que indican también cambios graduales dentro de una época específica y en mayor grado de una época a la otra.

\section{Agradecimientos}

Quiero agradecer al Dr. Miguel Cornejo por su apoyo y motivación para que este estudio se lleve a cabo y, especialmente a la Lic. Luisa Díaz quien con su constante apoyo, profesionalismo e interés por la sociedad Ychsma, ha permitido que este estudio sea posible.

\section{Referencias citadas}

BAZÁN, F., 1990 - Arqueología y Etnohistoria de los Períodos Prehispánicos Tardíos de la Costa Central del Perú; Lima: Universidad Nacional Mayor de San Marcos. Tesis para Optar el Titulo de Licenciado en Arqueología. Ms.

BONAVIA, D., 1959 - Cerámica de Puerto Viejo (Chilca). In: Actas del II Congreso Nacional de Historia del Perú,1958 (Vol. 1): 137-168; Lima: Centro de Estudios Históricos y Militares del Perú.

BONAVIA, D., 1962 - Sobre el estilo Teatino. Revista del Museo Nacional, 31: 43-94; Lima.

BRAGAYRAG, E., 1982 - Informe de las Excavaciones en la Huaca Marvavilca; Lima: Instituto Nacional de Cultura. Ms.

BUENO, A., 1982 - El Antiguo Valle de Pachacamac. Espacio, Tiempo y Cultura. Boletín de Lima, 24: 10-29.

BUENO, A., 1983 - El Antiguo Valle de Pachacamac. Espacio, Tiempo y Cultura (Segunda Parte). Boletín de Lima, 25: 5-27.

CANZIANI, J., 1983 - Una Ofrenda Inkaika en la Huaca B. Gaceta Arqueológica Andina, 2(7): 9-10; Lima: INDEA.

CASAS, L. \& DOLORIER, C., 2004 - Agricultores y tejedores de Huallamarca. Museo de sitio Huallamarca; Lima. Ms. 
COBO, F. B., 1882[1639] - Historia de la Fundación de Lima, 334p.; Lima: Imprenta Liberal. Publicación y notas de M. González de la Rosa.

CÓRDOVA, G. M., 2000 - Informe Final del Proyecto de Investigación Arqueológica en El Sauce o Campo Santo Alto; INC-COFOPRI. Ms

CORNEJO, M., 1992 - Cronología y costumbres sepulcrales en Lauri, valle de Chancay. In: Estudios de Arqueología Peruana (Bonavia, D., ed.): 311-354; Lima: Asociación Peruana para el Fomento de las Ciencias Sociales.

CORNEJO, M., 2000 - La nación Ischma y la provincia inka de Pachacamac. Arqueológicas, 24: 149-173; Lima: Museo Nacional de Arqueología e Historia del Perú.

CORNEJO, M., 2003 - Sacerdotes y tejedores en la provincia inka de Pachacamac. Boletín de Arqueología PUCP, 6: 171-204; Lima.

DIAZ, L., 1998 - Informe Técnico del Proyecto Arqueológico en la Modalidad de Rescate "Héroes del Pacifico" II Etapa; Lima. Ms.

DIAZ, L., 2000 - Informe del Proyecto Arqueológico de Rescate “A.H. San Pedro”- Armatambo, Chorrillos; Lima. Ms.

DIAZ, L., 2002 - Informe del Proyecto Arqueológico de Rescate "La Rinconada Alta"; Lima. Ms.

DIAZ, L., 2004a - Informe Final del Proyecto Arqueológico de Rescate “A.H. San Pedro Armatambo", Chorrillos; Lima. Ms.

DIAZ, L., 2004b - Informe Final del Proyecto Arqueológico de Rescate "A.H. 22 de Octubre Armatambo", Chorrillos; Lima. Ms.

DIAZ, L. \& VALLEJO, F., 2002-Identificación de Contextos Ichma en Armatambo. Arqueología y Sociedad, 14: 47-75; Lima: Museo de Arqueología y Etnología de la UNMSM.

DIAZ, L. \& VALLEJO, F., 2003a - Hallazgo de Pirámides con Rampa en Armatambo. Medio de Construcción, 175: 49-54; Lima.

DIAZ, L. \& VALLEJO, F., 2003b - Armatambo y el dominio incaico en el valle de Lima. Boletín de Arqueología PUCP, 6: 355-374; Lima.

DIAZ, L. \& VALLEJO, F., 2004 - Variaciones culturales en el valle de Lima durante la ocupación incaica. Chungara, Revista de Antropologia Chilena, 36(2): 295-302; Arica: Universidad de Tarapacá.

DISSELHOFF, H. D., 1961 - Amérique Précolombienne, les hautes civilisations du nouveau monde (Collection L'Art dans le Monde), 286p.; Paris: Editions Albin Michel.

EECKHOUT, P., 1995 - Pirámide con Rampa No 3 de Pachacamac, costa central del Perú. Resultados preliminares de la primera temporada de excavaciones (zonas 1 y 2). Bulletin de l'Institut Français d'Etudes Andines, 24(1): 65-106; Lima.

EECKHOUT, P., 1999 - Pirámide con Rampa N III, Pachacamac. Nuevos datos, nuevas perspectivas. Bulletin de l'Institut Français d'Etudes Andines, 28(2): 169-214; Lima.

ENGEL, F., 1984-Prehistoric Andean Ecology. Man, Settlement and Environment in the Andes, Chilca. Lima: Centro de Investigación de Zonas Áridas (CIZA) de la Universidad Nacional Agraria del Perú. Distribuido por Humanities Press para el Departamento de Antropología, Hunter College of the City, University of New York.

FELTHAM, J., 1983 - The Lurín Valley, Peru, A.D. 1000 - 1532; Londres: University of London. Ph.D. Thesis.

FRANCO, R., 1993 - Los dos Templos principales de Pachacamac. Revista del Museo de Arqueología, 4: 55-77; Trujillo.

FRANCO, R., 1998 - La Pirámide con Rampa $N^{o} 2$ de Pachacamac. Excavaciones y nuevas interpretaciones, 105p.; Trujillo.

FRANCO, R. \& PAREDES, P., 2000 - El Templo Viejo de Pachacamac. Nuevos aportes al estudio del Horizonte Medio. Boletín de Arqueología PUCP, 4: 607-630; Lima: Pontificia Universidad Católica del Perú. 
GONZALES, R., 2001 - La ocupación del valle medio de Chilca y los cambios climáticos en el Intermedio Tardío; Lima: UNMSM, E.A.P. de Arqueología. Ms.

GUERRERO, D., 1998 - Historia del Distrito de La Molina: Prehistoria (Tord, L., ed.): 63-107; Lima: Municipalidad de La Molina.

GUZMÁN, M., 2002 - Análisis del material Tardío recuperado en los trabajos en "El complejo de los Adobitos"- Pachacamac. Urpiwachak (Revista del Museo de Sitio Pachacamac): 19-27; Lima: INC.

HORKHEIMER, H., 1970 - Chancay prehispánico: diversidad y belleza. In: 100 años de la arqueología en el Perú: 363-378; Lima: Instituto de Estudios Peruanos y Petroperú.

HUDTWALCKER, J. \& PINILLA, J., 2004 - Proyecto Arqueológico San Lorenzo 2003 - 2004. Revista de Marina, 97(2): 55-64; Lima: Fondo de Publicaciones de la Dirección de Intereses Marítimos e Información de la Marina.

HYSLOP, J. \& MUJICA, E., 1992 - Investigaciones de A.F. Bandelier en Armatambo (Surco). Gaceta Arqueológica Andina, 6(22): 63-86; Lima: INDEA.

IRIARTE BRENNER, F., 1960 - Algunas apreciaciones sobre los Huanchos. In: Antiguo Perú; Espacio y Tiempo (Matos, R., ed.): 259-263; Lima: Editorial Juan Mejía Baca.

ISLA, J., 1995 - Materiales recuperados por Max Uhle (1906-1907) en la Isla de San Lorenzo, costa central del Perú. Gaceta Arqueológica Andina, 7(24): 73-91; Lima: INDEA.

KAUFFMANN, F., 1994 - Proyecto Arqueológico Tumbas de Ancón (I). Arqueológicas, (23): 9-87; Lima: Instituto Nacional de Cultura.

KAULICKE, P., 2001 - La Sombra de Pachacamac: Huari en la Costa Central. Boletín de Arqueología PUCP, (4): 313-358; Lima.

KROEBER, A., 1926 - Archaeological explorations in Perú. Cañete Valley. In: Anthropology Memoirs (Vol. 2): 219-273; Chicago: Field Museum of Natural History.

KRZANOWSKI, A., 1991 - Sobre la cerámica Chancay de tipo Lauri impreso. In: Estudios sobre la cultura Chancay, Perú, (Krzanowski, A., ed.): 215-242; Cracovia: Universidad Jaguelona.

MACHACUAY, M. \& ARAMBURÚ, R., 1998 - Contextos Funerarios Tardíos en La Salina, Valle del Rímac. Arqueología y Sociedad, 12: 37-50; Lima: Museo de Arqueología y Antropología UNMSM.

MAKOWSKI, K., 2003 - Arquitectura, estilo e identidad en el Horizonte Tardío: el sitio de Pueblo Viejo-Pucará, valle de Lurín. Boletín de Arqueología PUCP, 6: 137-170; Lima.

MASON, A., 1969 - Las Antiguas Culturas del Perú, 316p.; México, DF: Fondo de Cultura Económica.

MEJÍA, T., 1953 - Cultura Huaura. Ensayo de interpretación sobre su origen y desarrollo. El Comercio, El Dominical, 23. 08. 1953; Lima

MENZEL, D., 1968 - La Cultura Huari, 223p.; Lima: Compañía de Seguros y Reaseguros Peruano-Suiza. Las Grandes Civilizaciones del Antiguo Perú VI.

MENZEL, D., 1976 - Pottery style and society in ancient Perú. Arts as a Mirror of History in the Ica Valley, 1350-1570, Berkeley: University of California Press.

NEGRO, S. \& FUENTES, M. C., 1989 - Nieve-nieve: arquitectura y urbanismo en la costa central del Perú. Boletín de Lima, 62: 57-71; Lima.

PAREDES, P. \& FRANCO, R., 1989 -Proyecto: Templo Viejo de Pachacamac (Continuación de estudios). Segundo informe parcial, 2da. Temporada de Excavaciones; Lima: INC. Ms.

PAREDES, P. y RAMOS, J., 1994 - Excavaciones arqueológicas en el sector Las Palmas, Pachacamac. Boletín de Lima, 16(91-96): 313-349; Lima.

PEREZ, M., 1997 - Informe Final del Proyecto Arqueológico en la Modalidad de Rescate "Héroes del Pacífico"; Lima: I.N.C. Ms 
PEREZ, M. \& ARCE. S, 1989 - Chocas: asentamientos prehispánicos Tardíos en el valle bajo del Chillón, 42p.; Lima: UNMSM - CONCYTEC.

PURIN, S., 1990 - Inca-Perú. 3000 Ans d' Histoire, 503p.; Bruxelles: Musées Royaux d'Art et d'Histoire.

RAVINES, R., 1981 - Prácticas funerarias en Ancón (segunda parte). Revista del Museo Nacional, 45: 89-166; Lima.

RAVINES, R.,1994 - Las Culturas Preincas. Arqueología del Perú, 606p.; Lima: Editorial Brasa S.A. Historia General del Perú 2.

RAVINES, R. \& STOTHERT, K., 1976 - Un entierro común del Horizonte Tardío en la costa central del Perú. Revista del Museo Nacional, 42: 153-206; Lima.

REA, C., 2001 - Proyecto de Investigaciones Arqueológicas y Puesta en Valor de la Huaca San Borja; Lima: INC. Ms.

ROSTWOROWSKI, M., 1972-BreveEnsayo sobre el Señorío de Ychma o Ychima.Arqueología PUCP, 13: 37-51; Lima

ROSTWOROWSKI, M., 1978 — Los Señoríos Indígenas de Lima y Canta, 280 p.; Lima: Instituto de Estudios Peruanos.

RUALES , M., TOSSO, W. \& VALLEJO, F., 1983 - Informe de las Excavaciones de Rescate del Sector D1 de Armatambo. Informe Técnico; Lima: INC. Ms.

SCHMIDT, M., 1929 - Kunst und Kultur von Peru, 621p.; Berlin: Impropyläen- Verlag.

SHADY, R. \& RUIZ, A., 1979 - Huaura - Costa Central. Interacción regional en el periodo Intermedio Temprano. Arqueológica, 18: 1-95; Lima: Museo Nacional de Antropología y Arqueología - Instituto Nacional de Culura.

SILVA, J.,1992 - Ocupaciones Postformativas en el Valle del Rímac: Huachipa- Jicamarca. Revista del Museo de la Nación, I(1): 49-74; Lima.

STRONG, W. \& CORBETT, J., 1943 - A ceramic sequence at Pachacamac. Archaeological Studies in Peru 1941-1942, and Columbia Studies in Archaeology and Ethnology, 1(2): 29-121; New York.

TELLO, J. C., 1999 - Arqueología del Valle de Lima, 138p.; Lima: Museo de Arqueología y Antropología de la Universidad Nacional Mayor de San Marcos. Cuadernos de Investigación del Archivo Tello 1.

UHLE, M., 1903 - Pachacamac. Peruvian Expedition of 1896, 130p.; Philadelphia: Department of Archaeology, University of Pennsylvania.

VAlleJO, F., 1988 - Ritos Funerarios en el Perú Prehispánico. Análisis de una Tumba del Complejo Funerario de Armatambo, Lima. In: Ande: Prehistoria Come Progetto. Documenti de Etno-Archaeología Precolombiana: 381-443; Brescia: Universitá Católica dil Sacro Cuore.

VALLEJO, F., 1998 - Secuencia cronológica en base a la cerámica Ichma. In: Separata del Primer Coloquio de Arqueología del Valle del Rímac durante el Período Intermedio Tardio; Lima: INC - Museo de Puruchuco.

VILLACORTA,L.\& TOSSO,W., 2000-ElEstilo Teatino: Nuevas perspectivas. Arqueológicas: 24: 79-127; Lima: Museo Nacional de Arqueología, Antropología e Historia del Perú, INC.

WILLEY, G., 1943 - A supplement to the pottery sequence at Ancon. In: Archeological studies in Peru 1941-1942 and Columbia Studies in Archeology and Ethnology, 1(2): 199-215; New York. 